\title{
ART CCIM Phase II-A Off- Gas System Evaluation Test Plan
}

\author{
Nick Soelberg \\ Jay Roach \\ January 2009
}

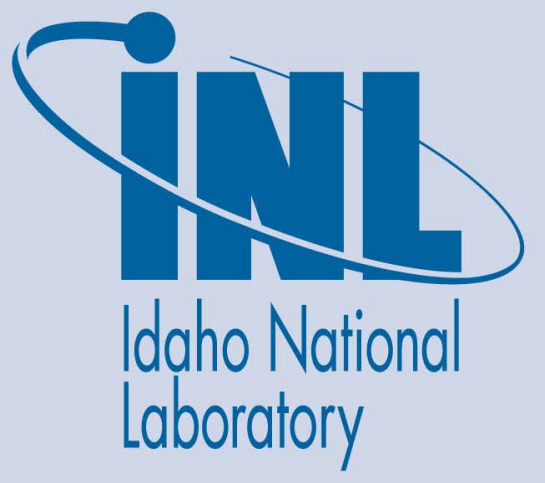

The INL is a U.S. Department of Energy National Laboratory operated by Battelle Energy Alliance 


\title{
ART CCIM Phase II-A Off-Gas System Evaluation Test Plan
}

\author{
Nick Soelberg \\ Jay Roach
}

January 2009

\section{Idaho National Laboratory \\ Idaho Falls, Idaho 83415}

http://www.inl.gov

Prepared for

AREVA Federal Services LLC

and for the

U.S. Department of Energy

Under DOE Idaho Operations Office

Contract DE-AC07-05ID14517 


\section{APPROVALS}

\begin{tabular}{|c|c|c|c|}
\hline Name & Title & Signature & Date \\
\hline Nick Soelberg & Project Engineer & & $26 \sqrt{4} 0 \%$ \\
\hline Jay Roach & Department Manager & & $01 / 27 / 09$ \\
\hline Eric Tchemitcheff & AREVA Project Manager & & $2 / 2 / 09$ \\
\hline
\end{tabular}


ART CCIM Phase II-A

INL/EXT-0814449

Off-gas System Evaluation Test Plan 


\section{SUMMARY}

This test plan defines testing to be performed using the Idaho National Laboratory (INL) engineeringscale cold crucible induction melter (CCIM) test system for Phase II-A of the Advanced Remediation Technologies (ART) CCIM Project. The multi-phase ART-CCIM Project is developing data and design information for the evaluation of replacing the joule-heated melter (JHM) used to treat high level waste (HLW) in the Defense Waste Processing Facility (DWPF) at the Savannah River Site (SRS) with a cold crucible induction melter. The INL CCIM test system includes all feed, melter off-gas control, and process control subsystems needed for fully integrated operation and testing.

Testing will include operation of the melter system while feeding a non-radioactive slurry mixture prepared to simulate the same type of waste feed presently being processed in the DWPF. Process monitoring and sample collection and analysis will be used to characterize the off-gas composition and properties, and to show the fate of feed constituents, to provide data that shows how the CCIM retrofit conceptual design can operate with the existing DWPF off-gas control system. 
ART CCIM Phase II-A

INL/EXT-0814449

Off-gas System Evaluation Test Plan 


\section{CONTENTS}

APPROVALS

Error! Bookmark not defined.

SUMMARY iii

ACRONYMS ix

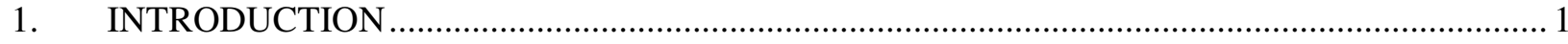

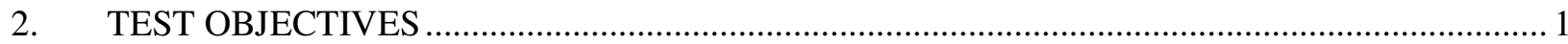

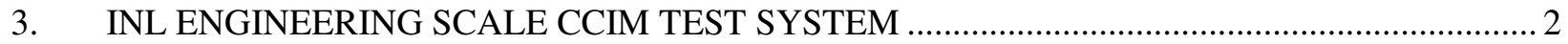

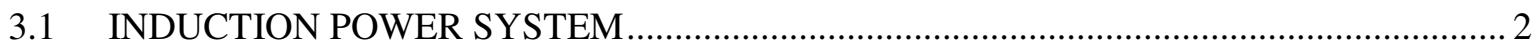

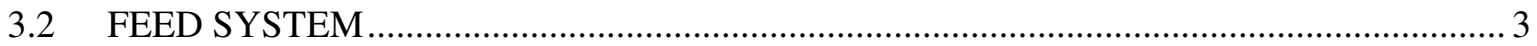

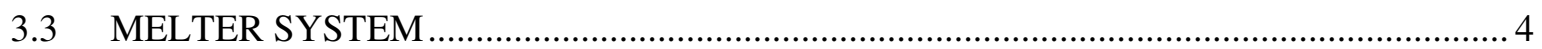

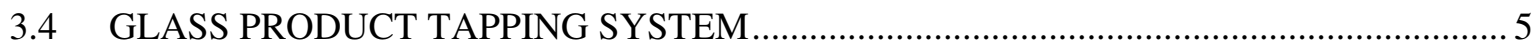

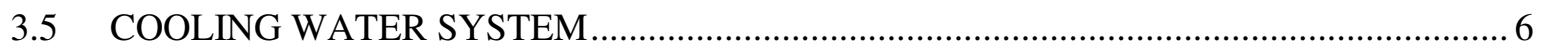

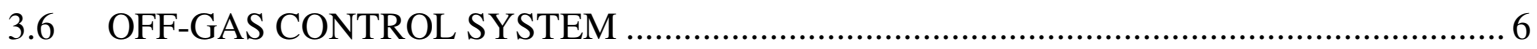

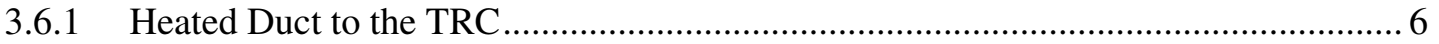

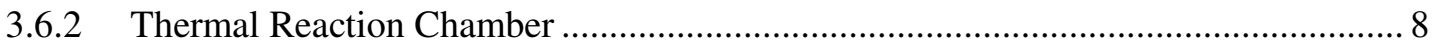

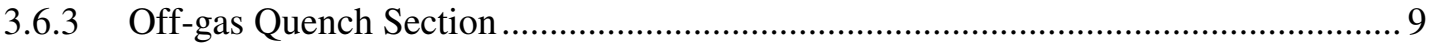

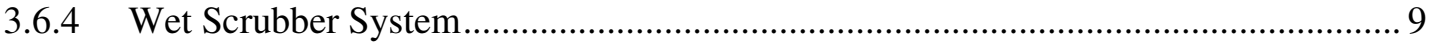

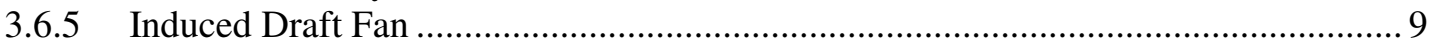

3.7 PROCESS MONITORING AND CONTROL SYSTEM …............................................. 9

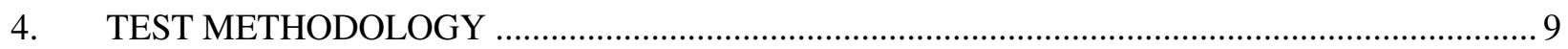

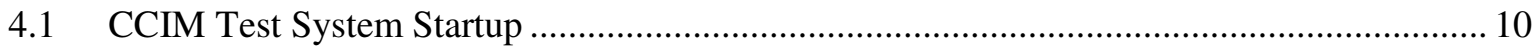

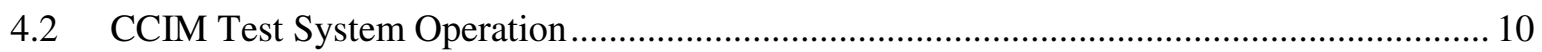

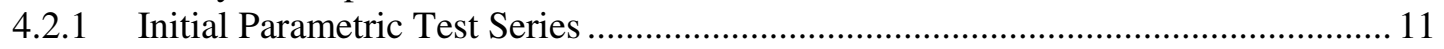

4.2.2 Off-gas System Evaluation Test Series................................................................ 12

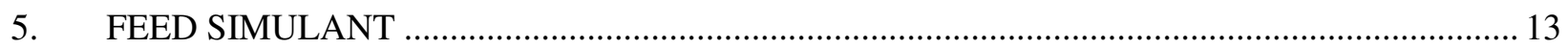

6. MEASUREMENTS, SAMPLE COLLECTION, AND SAMPLE ANALYSIS ............................ 20

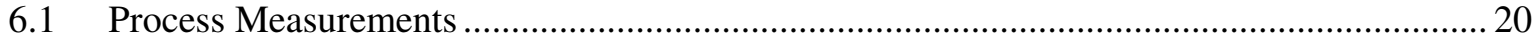

6.2 Continuous Emissions Monitoring System (CEMS) …...................................................... 21

6.3 Process Sample Collection and Analysis .......................................................................... 25

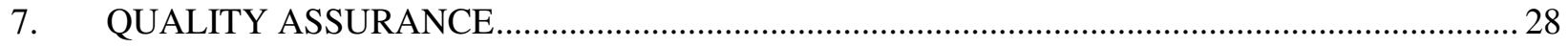

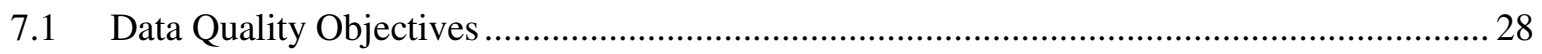

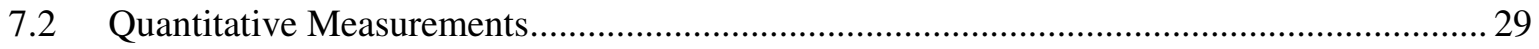

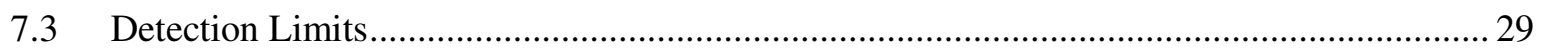

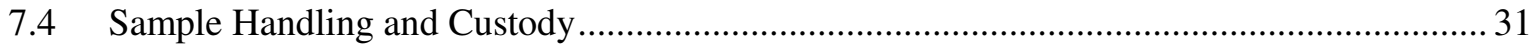

7.5 Data Reduction, Review, Validation And Reporting .................................................... 32 
Off-gas System Evaluation Test Plan

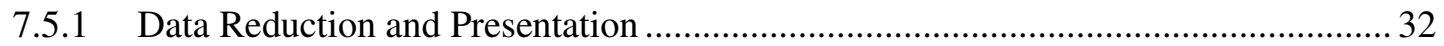

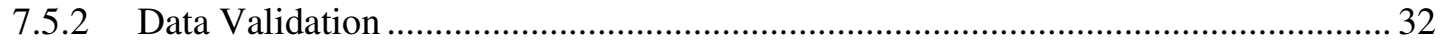

7.6 Internal Quality Control Checks and Specific Routine Procedures for Quality

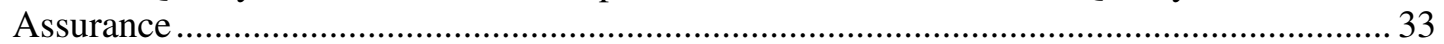

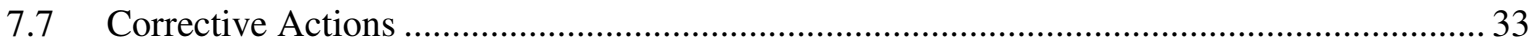

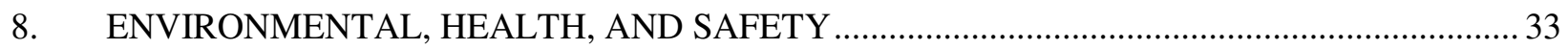

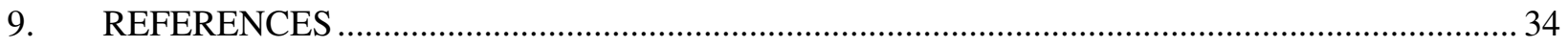

\section{FIGURES}

Figure 3-1. Simplified process schematic of the INL CCIM test system. ............................................. 3

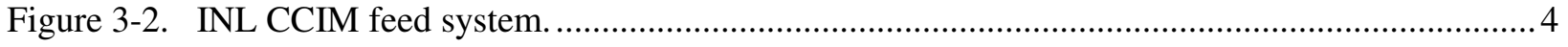

Figure 3-3. INL CCIM cooling water system schematic. ................................................................ 7

Figure 3-4. INL CCIM test system off-gas control system.............................................................. 8

Figure 6-1. CEMS for INL CCIM process gas measurements at the melter outlet sample location.........24

\section{TABLES}

Table 5-1. Composition of the calcined solids for the simulant for Sludge Batch 4 (no frit).................. 14

Table 5-2. SB4 simulant composition normalized to feed composition basis (no frit)............................ 15

Table 5-3. Sludge Batch 4 waste simulant fabricated by Harrell Industries, Inc. analytical results ......... 16

Table 5-4. Frit 503-R6 composition for the ART CCIM Phase II-A demonstration tests......................... 17

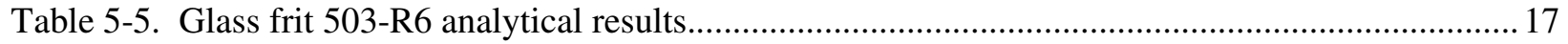

Table 5-6. Calculated composition of simulant SB4 feed slurry including glass frit 503 R6.................. 18

Table 5-7. Calculated product glass composition including glass frit 503 R6 ....................................... 19

Table 5-8. Startup glass (503-R6/SB4 at $46 \mathrm{wt} \%$ waste loading) analytical results.................................20

Table 6-1. Key process data that is electronically or manually logged...................................................22

Table 6-2. Typical analyzers used in the continuous emission monitoring (CEM) systems. ...................25

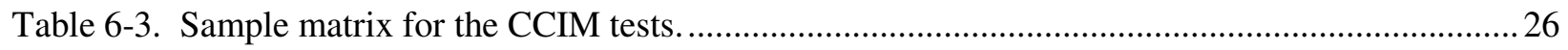

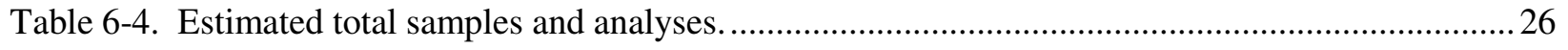

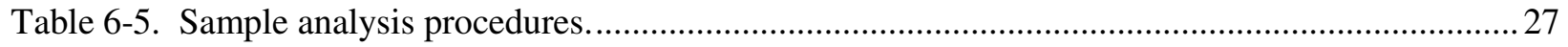

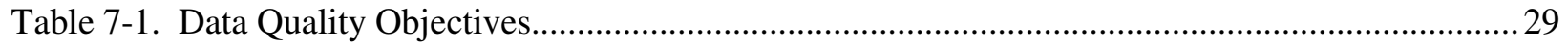

Table 7-2. Precision, accuracy, and completeness objectives for critical measurements........................30 


\section{ACRONYMS}

\begin{tabular}{|c|c|}
\hline $\begin{array}{l}\text { APAD } \\
\text { ART }\end{array}$ & $\begin{array}{l}\text { Air Permit Applicability Determination } \\
\text { Advanced Remediation Technologies }\end{array}$ \\
\hline $\begin{array}{l}\text { C } \\
\text { CCIM } \\
\text { CEA } \\
\text { CEM } \\
\text { CEMS }\end{array}$ & $\begin{array}{l}\text { critical } \\
\text { cold crucible induction melter } \\
\text { Commissariat a l'Energie Atomique } \\
\text { continuous emissions monitoring } \\
\text { continuous emissions monitoring system }\end{array}$ \\
\hline $\begin{array}{l}\text { DACS } \\
\text { DWPF }\end{array}$ & $\begin{array}{l}\text { data acquisition and control system } \\
\text { Defense Waste Processing Facility }\end{array}$ \\
\hline HLW & high level waste \\
\hline $\begin{array}{l}\text { ID } \\
\text { IDL } \\
\text { IEDF } \\
\text { INL } \\
\text { ISMS }\end{array}$ & $\begin{array}{l}\text { induced draft } \\
\text { instrument detection limit } \\
\text { INL Engineering Demonstration Facility } \\
\text { Idaho National Laboratory } \\
\text { Integrated Safety Management System }\end{array}$ \\
\hline JHM & joule-heated melter \\
\hline LI & Laboratory Instruction \\
\hline MDL & method detection limit \\
\hline $\mathrm{NC}$ & non-critical \\
\hline OGSE & off-gas system evaluation \\
\hline $\begin{array}{l}\text { PARCC } \\
\text { P\&ID } \\
\text { PIC } \\
\text { PUREX }\end{array}$ & $\begin{array}{l}\text { precision, accuracy, representativeness, completeness, comparability } \\
\text { process and instrumentation diagram } \\
\text { products of incomplete combustion } \\
\text { Plutonium and Uranium REcovery by Extraction }\end{array}$ \\
\hline REDOX & reducing/oxidizing \\
\hline $\begin{array}{l}\text { QA/QC } \\
\text { QLD } \\
\text { Qual } \\
\text { Quant }\end{array}$ & $\begin{array}{l}\text { quality assurance / quality control } \\
\text { Quality Level Determination } \\
\text { qualitative } \\
\text { quantitative }\end{array}$ \\
\hline $\begin{array}{l}\text { RF } \\
\text { RFA/COC }\end{array}$ & $\begin{array}{l}\text { radio frequency } \\
\text { request for analysis/chain of custody }\end{array}$ \\
\hline $\begin{array}{l}\text { SAIC } \\
\text { SRNL } \\
\text { SRS }\end{array}$ & $\begin{array}{l}\text { Science Applications International Corporation } \\
\text { Savannah River National Laboratory } \\
\text { Savannah River Site }\end{array}$ \\
\hline $\begin{array}{l}\text { THC } \\
\text { TRC }\end{array}$ & $\begin{array}{l}\text { total hydrocarbon } \\
\text { thermal reaction chamber }\end{array}$ \\
\hline
\end{tabular}


ART CCIM Phase II-A

Off-gas System Evaluation Test Plan

UDS undissolved solids

WESP wet electrostatic precipitator 


\section{ART CCIM Off-gas System Phase II-A Evaluation Test Plan}

\section{INTRODUCTION}

This test plan defines testing to be performed using the Idaho National Laboratory (INL) engineeringscale cold crucible induction melter (CCIM) test system for Phase II-A of the Advanced Remediation Technologies (ART) CCIM Project. The multi-phase ART-CCIM Project is designed to develop data and design information for the evaluation of replacing the joule-heated melter (JHM) used to treat high level waste (HLW) in the Defense Waste Processing Facility (DWPF) at the Savannah River Site (SRS) with a cold crucible induction melter. Phase II-A includes performing tests using the engineering-scale INL CCIM test system and a larger pilot-scale CCIM test system in Marcoule, France.

Tests will be performed in both test systems because each system provides unique features that are needed in this project. The pilot-scale CCIM, with a nominal melter diameter of $650 \mathrm{~mm}$, is almost 6 times larger than the $267 \mathrm{~mm}$ INL CCIM (in terms of melt surface cross-section area), and is within a factor of about 4 of an expected full-scale CCIM for the DWPF. Testing at both scales will provide performance and scaling information needed for future full-scale system design and operation. The INL CCIM is equipped with an integrated off-gas system with high efficiency $\mathrm{NO}_{\mathrm{x}}$ and organics destruction and high efficiency collection and control of particulate matter, radionuclide surrogates, heavy metals, and acid gases.

\section{TEST OBJECTIVES}

The primary objective of the Off-gas System Evaluation Test is to characterize the off-gas composition and properties to provide data that shows how the CCIM retrofit conceptual design can operate with the existing DWPF off-gas treatment system. The INL CCIM test system is well-suited for this test objective because (a) its smaller size (compared to the larger pilot-scale CCIM) requires less feed simulant from SRNL, (b) it is already configured with an integrated off-gas system that can destroy $\mathrm{NO}_{\mathrm{x}}$ and organic emissions, scrub acid gases and particulate matter, and (c) the test system can generate data to determine the fate of feed constituents (especially Cs).

Detailed test features that will accomplish this objective include:

- Operate the melter system while feeding a nonradioactive simulant representing the SRS HLW sludge waste, during operating conditions selected to represent potential conditions expected for larger CCIM systems. Operating conditions expected to influence off-gas emissions and the fate of feed constituents include (a) glass and freeboard temperatures, (b) use of melt agitation, (c) degree of cold cap coverage, (d) melt residence time, and (g) freeboard gas turbulence and velocity. The simulant feedrate will be set to approximate the specific feedrate $\left(\mathrm{L} / \mathrm{hr} / \mathrm{m}^{2}\right)$ of larger CCIM systems. A single bubbler will be used to provide melt agitation in addition to the convection currents in the glass caused by temperature differentials.

- Determine the melter off-gas source term to the off-gas system. This includes measuring the off-gas composition and also measuring amounts and composition of entrained and volatilized particulate matter at the outlet of the melter, for selected melter operating conditions listed above.

- Determine compositions and masses of the product glass and scrub solution, and the glass REDOX levels as indicated by the REDOX ratio $\left(\mathrm{Fe}^{+2} / \mathrm{Fe}^{\text {total }}\right)$. 
- Determine the fate of key feed constituents (glass formers, radionuclide surrogates, toxic metal surrogates, nitrates/nitrites, organics, and acid gases)

\section{INL ENGINEERING SCALE CCIM TEST SYSTEM}

The INL has developed, tested and used technologies to treat, store, and dispose of radioactive, hazardous, and industrial wastes and spent nuclear fuel generated or stored at the INL in a safe, cost-effective, and environmentally sound manner. The INL developed and operated large-scale fluidized bed calcination systems for HLW stabilization, which is the only non-vitrification technology that has been used to date in the United States. The INL has also designed, tested, or operated metal and glass melters, incinerators, evaporators, catalytic oxidizers, and thermal desorbers for radioactive and mixed waste treatment. These thermal treatment systems have included off-gas characterization and state-of-the-art off-gas control systems. Consequently, the INL has developed extensive expertise in offgas characterization, monitoring, and control.

The INL is the only DOE facility to have a fully integrated CCIM test system including solid and liquid/slurry feed systems, and a complete off-gas treatment system designed to comply with the most rigorous air emission regulatory requirements. The laboratory has been researching, modeling and publishing on the CCIM technology for 5 years.

The INL CCIM test system (Figure 3-1) includes the following subsystems:

- Induction power system

- Feed system

- Melter system

- Glass product tapping system

- Cooling water system

- Off-gas control system

- Process monitoring and control system

\subsection{INDUCTION POWER SYSTEM}

Major components of the induction power system include a Taylor-Winfield Thermionic C-6000 radio frequency (RF) generator, a coil transfer relay, and the induction coil. The frequency generator itself consists of three subsystems which are an enclosed plate transformer unit, a high frequency generator chassis, and a control workstation. The enclosed transformer receives $480 \mathrm{~V}$ input power from the INL Engineering Demonstration Facility (IEDF) and supplies nominal 15-kV, 3-phase power to the generator chassis. The $15 \mathrm{kV}$ transformer output, which is rectified with a 3-phase, full-wave bridge in the chassis, is subsequently filtered to provide low-ripple direct current to the triode oscillator. Varying the angle of the firing system allows programming the plate voltage to the triodes, thus controlling output power.

The induction power system provides induction power of up to $60 \mathrm{kWe}$ at a nominal frequency of approximately $2.6 \mathrm{MHz}$. The power level is adjustable via the control panel or 4-20 mA computer interface continuously over the range of $10-60 \mathrm{kWe}$. The generator can also be configured to provide full power at a single frequency over a frequency range of $200-400 \mathrm{kHz}$ and $1.6-4 \mathrm{MHz}$. The maximum design power output is $75 \mathrm{kWe}$, but overpower interlocks limit the maximum power to $60 \mathrm{kWe}$ without readjustment. 


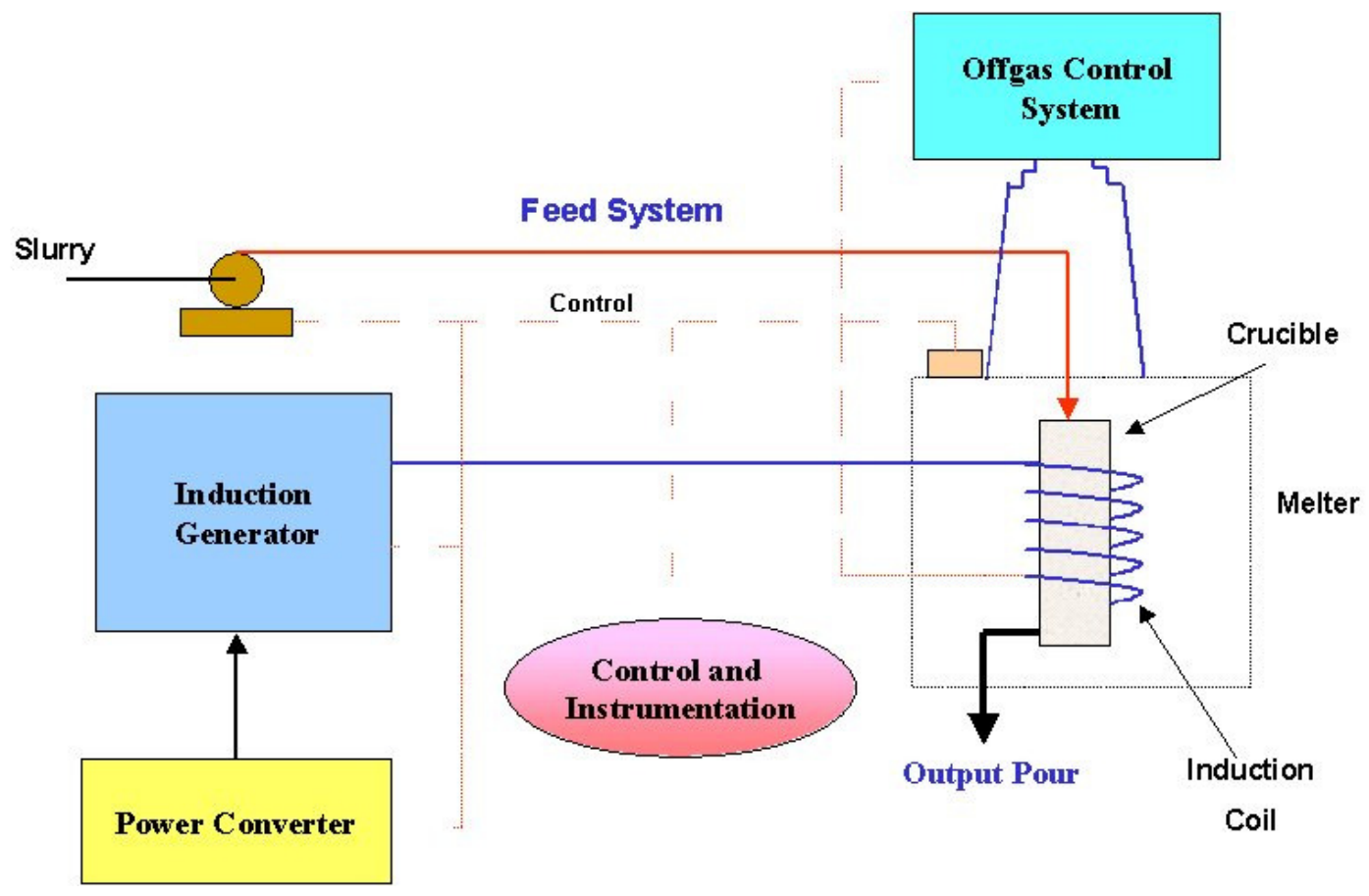

Figure 3-1. Simplified process schematic of the INL CCIM test system.

The target frequency for this test, to best emulate the energy deposition profile in the Commissariat a l'Energie Atomique (CEA) CCIM demonstration system in Marcoule, France, is 1.6 MHz (Girold 2008).

Radiated emissions from the system are governed for whole-body human radiated susceptibility by ANSI/IEEE Standard C95. 1, Standard for Safety Levels with Respect to Human Exposure to Radio Frequency Electromagnetic Fields, $3 \mathrm{KHz}$ to $300 \mathrm{GHz}$. Standard industrial practice allows operation with no additional shielding, but, at present time, a conductive metal cage called a Faraday shield is installed to provide additional shielding for personnel protection during operation.

Operating parameters within the power supply system are continuously monitored. If certain conditions exceed preset safe values, the power supply system is automatically shut down. In addition, multiple and redundant safety interlocks are provided to protect operators.

\subsection{FEED SYSTEM}

The test system is configured with a feed system capable of delivering liquid, slurry, or solid granular or powdered materials. The liquid feed system, shown in Figure 3-2, includes a feed tank for mixing and feeding liquids or slurries. The feed tank is equipped with a stirrer to maintain homogeneity in slurry feed mixtures. A recirculation pump draws feed solution from the feed tank and recycles it back to the feed tank, which improves mixing in the feed tank. A separate metering pump provides flow metering and control, drawing feed from downstream of the recirculation pump. A mass flowmeter provides the flowrate measurement that is logged continuously by the data acquisition and control system (DACS). 


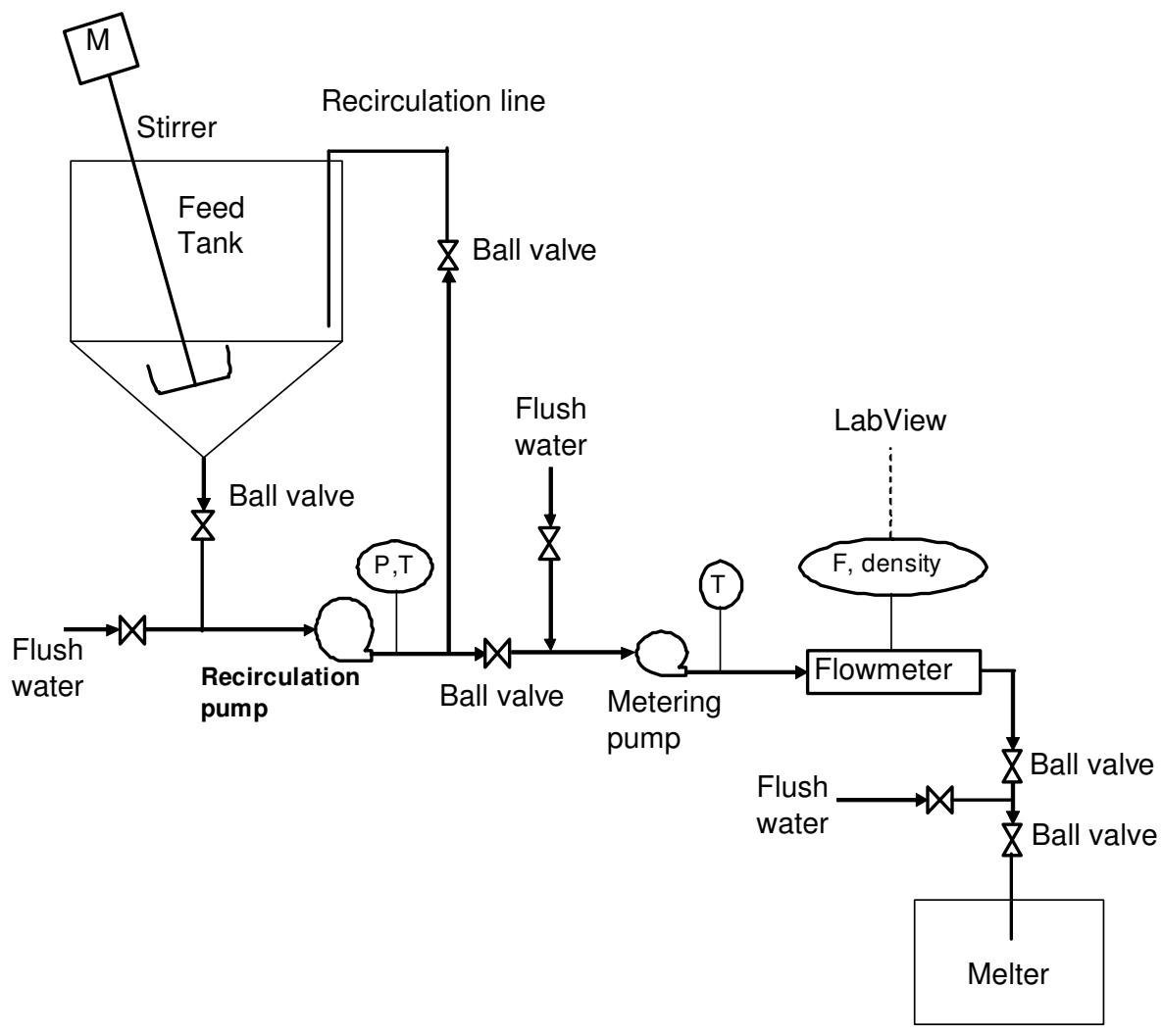

[ccim offgas system design calculations aug 2508 08.xls]Feed system

Figure 3-2. INL CCIM feed system.

The feed system is designed with the capability to feed water during startup and shutdown, and for flushing the feed system to clear it of potential plugging from UDS or glass frit in the feed slurry.

Feeds are deposited near the center of the crucible, on top of the melt, in line with a view port and monitoring camera. The viewport enables visual observation of surface cover and turbulence.

\subsection{MELTER SYSTEM}

The melter crucible contains the molten melt material. It is constructed of 304L stainless steel, and consists of three primary components: the lower manifold, the upper manifold, and the cooling tubes. The crucible wall consists of vertical water-cooled tubes oriented to form a crucible cylinder with a nominal $26.7 \mathrm{~cm}$ (10.5 inches) internal diameter. The overall crucible height is $40.6 \mathrm{~cm}$ (16 inches).

During operation, the water-cooled tubes cause glass adjacent to the tubes to solidify into a solid skull wall that forms the crucible enclosure, while maintaining appropriate temperatures in the crucible walls. The crucible water cooling system can provide adequate cooling at the nominal full generator power $(60 \mathrm{~kW})$ and with a glass temperature up to $2,000^{\circ} \mathrm{C}$.

Liquid and solid feeds are fed to the top of the molten melt inside the melter crucible, using tubes that penetrate through the melter lid. In this test, only a liquid slurry feed will be used. Solid glass frit used at initial startup will be added manually. As the water in the slurry feed is evaporated, REDOX reactions occur between reductants and oxidants in the feed, and the dried residues heat to melt temperatures and become incorporated into the melt. New fresh feed is continuously or semicontinuously fed. The feed is 
heated and melted via heat transfer from the molten bath, which in turn is inductively heated by the electrical induction field.

During this test, all available lid penetrations will be utilized as follows:

- Three site ports will be used for visual and camera observations of the glass melt.

- One site port will be converted to use as the slurry feed port.

- One port will be used for glass melt temperature measurements.

- One port will be used for an air bubbler. The target air bubbler rate, to best emulate the operation of the CEA Marcoule CCIM, is 1-1.5 lpm (Girold 2008).

Although glass melt stirring is planned in the CEA Marcoule test, the ART CCIM Phase II-A project team has concurred that stirring will not be included in the off-gas system evaluation (OGSE) tests. Adequate and representative glass melt mixing is expected to be achieved in this small melter by the convective currents and by using the bubbler, which also best emulates the potential for entraining melt aerosols and dust.

The crucible lid consists of an internal inconel shell that encloses the crucible freeboard space, which is covered with an outer stainless steel shell. The internal space between the inner and outer shells of the lid can be air or steam-cooled, or uncooled. Water cooling is not used here, as it would cause the lid to be too cool and cause condensation and deposition of material inside the lid during operation.

The melt height inside the crucible varies as the feed is continuously fed and the glass is semicontinuously tapped. The melt height can range between $10.2-30.5 \mathrm{~cm}$ ( $4-12$ inches), but the nominal design height is $26.7 \mathrm{~cm}$ (10.5 inches), equal to the melt diameter. The freeboard volume above the nominal melt height inside the crucible is $7,800 \mathrm{~cm}^{3}\left(476 \mathrm{in}^{3}\right)$. The melter lid, which is the same diameter and $15 \mathrm{~cm}$ (5 inches) high, adds an additional $7,090 \mathrm{~cm}^{3}\left(433 \mathrm{in}^{3}\right)$. The total nominal freeboard volume is about $14,890 \mathrm{~cm}^{3}\left(909 \mathrm{in}^{3}\right)$.

\subsection{GLASS PRODUCT TAPPING SYSTEM}

As the molten bath volume increases from added melted feed, the glass is drained semicontinuously depending on the glass production rate. The existing crucible includes a bottom drain assembly, which allows draining the crucible down to about a 4-inch depth, so that a sufficient height of molten glass remains in crucible to remain coupled with the induction field.

The tapped glass exits the tapper and gravity drains into a receiving canister resting in a catch basin. The CCIM will have only a small molten glass inventory in process at any given time, ranging to as much as $17,000 \mathrm{~cm}^{3}\left(1,040 \mathrm{in}^{3}\right)$. The catch basin is sized to contain the full volume of glass in the melter if necessary, to avoid spilling molten glass onto the laboratory floor. 


\subsection{COOLING WATER SYSTEM}

Several of the power supply and melter components are water cooled:

- The RF generator

- The induction coil

- The melter crucible

- Depending on design, the glass tapper

The cooling water system, shown schematically in Figure 3-3, consists of two primary and secondary loops. The primary loops circulate cooling water through the cooled components to liquid-liquid heat exchangers. This loop is internal to the facility and requires no freeze protection. The secondary loops circulate water and antifreeze mixtures from the heat exchangers to an outdoor water chiller (for one loop) and a radiator (for the other loop). The antifreeze provides freeze protection of the secondary loop. All coolant is recirculated, generating no secondary waste. The water chiller is used to maintain the primary coolant loop for the RF generator below the shutoff temperature of the generator.

The CCIM power supply is interlocked with the cooling water outlet temperature, and is automatically de-energized if the cooling water outlet temperature exceeds a safe preset temperature and flowrate.

In the event of a failure of the crucible cooling system, both facility water and water that is gravity fed from an upper-deck reservoir can provide once-through cooling water. This ensures that, even if the cooling water system fails, and the power to the melter is stopped, crucible cooling continues for a long enough time for the crucible to cool to a safe temperature $\left(<100^{\circ} \mathrm{C}\right)$ at which the water can be shut off.

\subsection{OFF-GAS CONTROL SYSTEM}

The CCIM off-gas system is shown in Figure 3-4. The off-gas system was designed to include these components:

- Heated duct to the thermal reaction chamber (TRC)

- Thermal reaction chamber

- Off-gas quench section

- Wet scrubber system

- Induced draft fan

\subsubsection{Heated Duct to the TRC}

A prototype heated inconel duct enables flow of off-gas from the melter to the TRC. This $79 \mathrm{~cm}(31$ in) long, $7 \mathrm{~cm}$ ( $2.8 \mathrm{inch})$ inside diameter duct is angled at 45 degrees from horizontal, and heated using a high-temperature electric resistance heating element to heat the duct wall up to $800^{\circ} \mathrm{C}$ if desired. The inside volume of this duct is about $2,910 \mathrm{~cm}^{3}\left(177 \mathrm{in}^{3}\right)$, about $16 \%$ of the total freeboard volume of the melter, lid, and duct. 

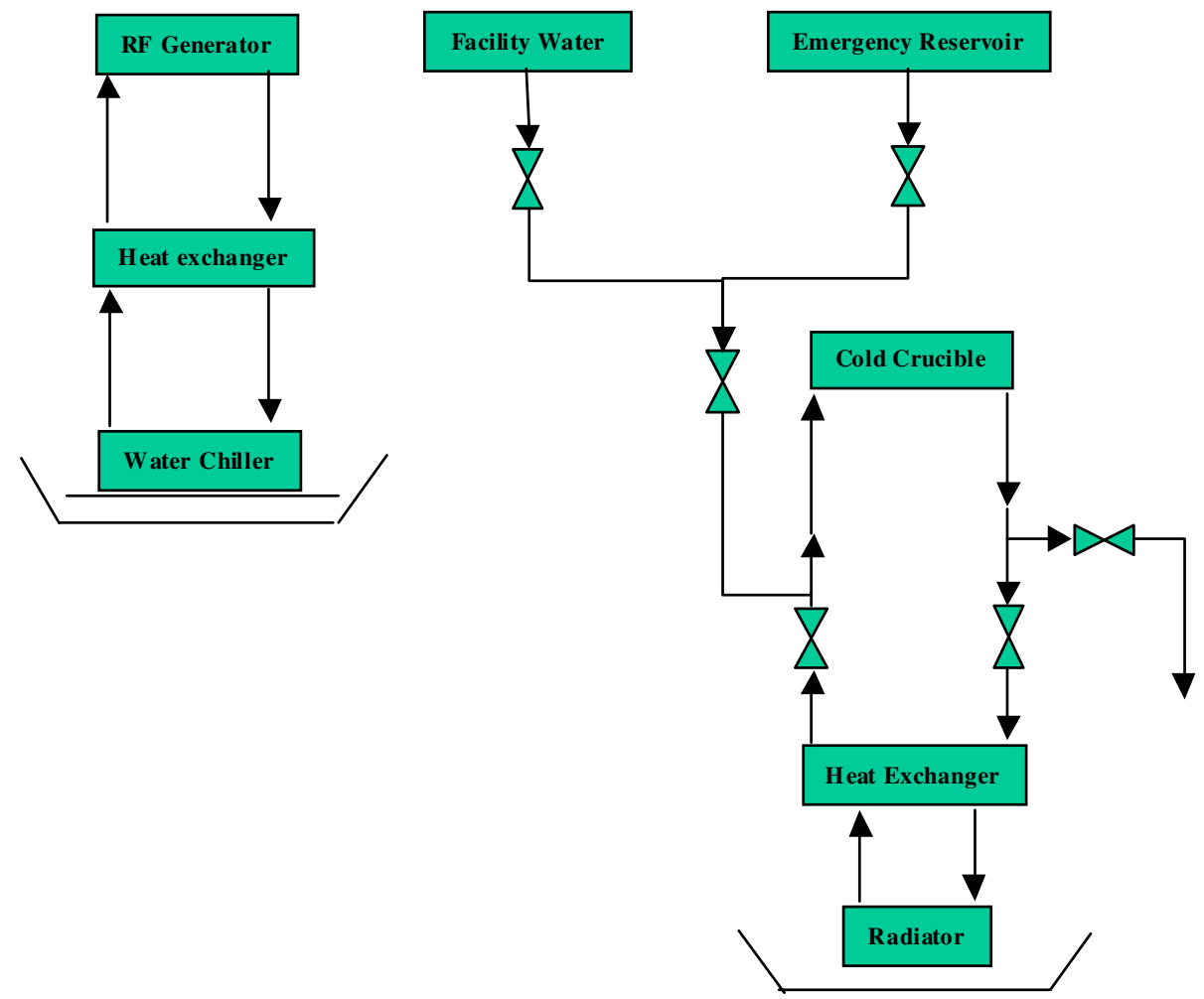

Figure 3-3. INL CCIM cooling water system schematic.

The slope and the heated wall of this duct is designed to minimize gas condensation and particulate deposition, and will encourage particulate deposits that do form to fall or melt and drain back into the melter. This design has been used successfully in prototype electric arc melter systems designed for treating solid hazardous and mixed wastes. This avoids dilution of the melter off-gas (sometimes by a factor of 2-10x) that would occur if a film cooler were used to minimize particulate deposition at this location, thereby minimizing the downstream off-gas flowrate and sizes of downstream off-gas equipment. An observation/cleanout port is located in the wall of the TRC opposite the end of this duct, to enable monitoring and cleanout of this duct, if necessary, during operation.

This duct can be operated with the heater off, if desired to avoid heating the off-gas and better emulate the process gas time-temperature history of larger CCIM systems. For this test, this duct will be heated sufficiently to avoid significantly heating or cooling the melter process gas.

The sample port for collecting process off-gas samples downstream of the melter is located near the outlet of this heated duct, 10 duct diameters downstream of the melter outlet and 1 diameter upstream of the inlet to the TRC, which is a suitable location for isokinetic particulate sampling in small ducts according to U.S. EPA Method 1A ("Sample and Velocity Traverses for Stationary Sources with Small Stacks or Ducts," 40 CFR 60, Appendix A).

Two sample points are available for continuous emissions monitoring system (CEMS) measurements. One location is at the inlet the heated duct, and the other is at the inlet to the TRC. Measurements may be made at both locations to determine the most ideal location. 


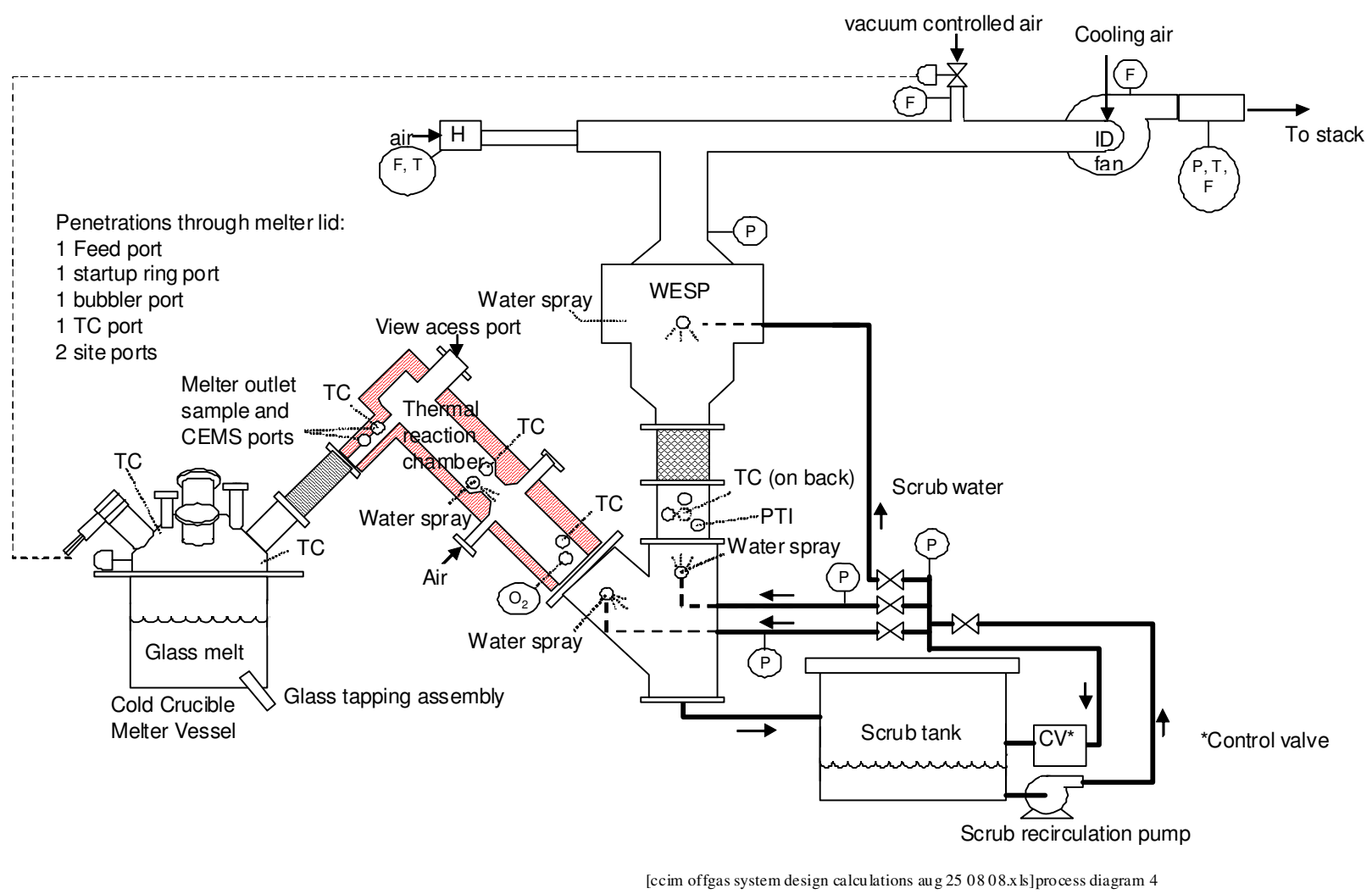

Figure 3-4. INL CCIM test system off-gas control system.

\subsubsection{Thermal Reaction Chamber}

The TRC is designed to perform nonselective, noncatalytic, thermal $\mathrm{NO}_{\mathrm{x}}$ reduction and also fully oxidize any reduced gas species such as $\mathrm{H}_{2}, \mathrm{CO}$, or $\mathrm{CH}_{4}$. The off-gas is heated in the first stage using electrical heating to $\mathrm{NO}_{\mathrm{x}}$ reduction reaction temperatures (of around $800-1,000^{\circ} \mathrm{C}$ ) using an electric immersion heater. The immersion heater has a maximum temperature rating of $1,200^{\circ} \mathrm{C}$. The reaction chamber is sized and configured to provide adequate heat transfer surface area, mixing, and residence time to heat and maintain the gas at the design temperature for at least 2-seconds residence time.

$\mathrm{NO}_{\mathrm{x}}$ destruction is not an objective of this test, as the DWPF does not include $\mathrm{NO}_{\mathrm{x}}$ destruction in the off-gas system. Instead, this chamber will be used in this test to demonstrate conditions under which incompletely oxidized species (from the reductant in the feed) are oxidized to $\mathrm{CO}_{2} . \mathrm{NO}_{\mathrm{x}}$ levels and $\mathrm{NO}_{\mathrm{x}}$ destruction will also be measured, although the process will not be optimized for high $\mathrm{NO}_{\mathrm{x}}$ destruction. Conditions that may be varied during testing include the TRC gas temperature and stoichiometry.

The second stage of the TRC provides the capability of evaporative cooling of a water spray into the off-gas to cool the $\mathrm{NO}_{\mathrm{x}}$-reduced off-gas to about $800^{\circ} \mathrm{C}$, if the TRC is operated in the $\mathrm{NO}_{\mathrm{x}}$-reduction mode. This is not expected to be used in this test series, as it is not needed unless the first stage is operated at high temperatures $\left(>800^{\circ} \mathrm{C}\right)$.

In the oxidizer section, air is normally added to provide oxygen for complete oxidation of $\mathrm{CO}$ and other products of incomplete combustion (PICs) that were formed or remain in the reducing section off-gas. The oxidizer section is designed consistent with typical efficient thermal oxidizer designs, with a 
residence time of at least 2 seconds. The temperature is controlled to avoid exceeding about $1,000^{\circ} \mathrm{C}$ by the water spray in stage two, to avoid excessive thermal $\mathrm{NO}_{\mathrm{x}}$ formation that could occur if temperatures significantly exceeded $1,000^{\circ} \mathrm{C}$. During this test series, since the TRC is not expected to be operated with separate reducing and oxidizing stages which would be needed for efficient $\mathrm{NO}_{\mathrm{x}}$ destruction, air addition in this stage is not expected to be necessary. Instead, sufficient air for stoichiometry control will be added in the first stage of the TRC.

\subsubsection{Off-gas Quench Section}

Following thermal oxidation the off-gas is cooled (quenched) by water spray evaporation to the adiabatic dewpoint of the off-gas with the added evaporated water. This section is constructed of Hastelloy steel to tolerate the initially high off-gas temperature and to provide good resistance to corrosion at both high and low temperatures.

\subsubsection{Wet Scrubber System}

Immediately following the temperature quench stage, the off-gas will pass through a wet scrubber designed to remove acid gases and some of the residual particulate matter. The scrubber system includes the high performance scrubber itself, the scrub tank that collects and holds scrub solution, and the scrub solution recirculation system. The recirculation system includes a pump, valves, and piping to recirculate scrub solution to the spray quench nozzles in the off-gas quench section, and to the scrubber.

The scrubber is a wet electrostatic precipitator (WESP). The WESP uses electrical energy to charge entrained particulate matter and condensed water droplets, causing them to migrate to the collector walls. The WESP is self-cleaning. The electrodes are electrically isolated from the collectors, and purged with a dry air flowrate to prevent moisture condensation at this location.

\subsubsection{Induced Draft Fan}

The induced draft (ID) fan provides the motive force to draw the off-gas from the melter through the off-gas system. Since off-gas flowrates may vary widely under different test conditions, the ID fan is equipped with flow/pressure control dampers, and upstream, damper-controlled addition of ambient air to augment and control the total gas flowrate and vacuum.

\subsection{PROCESS MONITORING AND CONTROL SYSTEM}

The CCIM test system is continuously monitored and controlled using a computer-based data acquisition and control system (DACS). The system includes a control computer, LabVIEW software, P\&ID displays, the Instrument Interface, plant instruments, the Control Interface, plant controls, and a video monitoring system. Key parameters for all subsystems are continuously monitored and controlled. Specific parameters that are continuously measured and recorded include temperatures, pressures, voltages, power levels, flowrates, and off-gas composition.

\section{TEST METHODOLOGY}

Test operations will be performed to accomplish the test objectives. Test operating procedures developed in prior tests will be followed. All test activities conducted by INL will be performed in accordance with the Idaho National Laboratory Quality Assurance Program Requirements Documents (Laboratory Wide Manual 13), or other specific standards, which meet or exceed the requirements of DOE O 414.1C, Quality Assurance. All test activities will also comply with INL's Integrated Safety 
Management System (ISMS) and applicable work authorizing documentation. These documents include the current versions of:

- Laboratory Instruction 1366-08-IEDF, "Cold Crucible Induction Melter (CCIM) Project" (LI 1366-08 record doc aug 6 08.pdf, 6 August 2008)

- Air Permit Applicability Determination for the Cold Crucible Induction Melter (CCIM) Project (APAD, IRC 08 - 03013 rev 1 IRC calciner, cold crucible.doc, 6 August 2008).

- Quality Level Determination (QLD REC-000043.pdf, 24 July 2008).

- Environmental Checklist (EC - Cold Crucible Induction Melter Testing INL-08-064 (QA8).doc)

- CCIM test system standard operating procedures

INL staff and subcontractors will maintain and operate the test facility, including pre-test preparations, test performance, sample collection, and facility maintenance. These personnel are trained in applicable safety, quality assurance, and facility-specific operating procedures.

\subsection{CCIM Test System Startup}

The test system startup will include the following components:

- Complete pre-start procedure (make ready and power-on all subsystems per the startup sequence).

- Ensure that the feed tank is well stirred and circulated to suspend frit and undissolved solids (UDS).

- Add start up glass and starting media to the crucible.

- Start all subsystems in the proper sequence (cooling systems, induction power generator, TRC, wet scrubber, and ID fan) according to startup procedures.

- As the startup glass heats in the crucible, make adjustments to tune the induction power as needed for heatup. Monitor all other system parameters, especially the cooling systems.

- When the glass in the crucible is molten and has reached the target melt temperature, and other subsystems (cooling systems, TRC, wet scrubber, and ID fan) are operating within their startup parameters, then the melter is ready to start simulant feed.

- Start simulant feed following the simulant startup checklist, which includes verification/ adjustment of all system operating conditions prior to starting simulant feed.

- Adjust melter power levels, cooling system flowrates, and off-gas system parameters to reach and stabilize operation at the target operating conditions.

\subsection{CCIM Test System Operation}

The test system is operated to accomplish the test objectives. Process conditions are either automatically or manually controlled to maintain stable conditions at each test condition, to the extent practical.

The scope of testing will include operating the test system at selected operating conditions, while recording data that are continuously, electronically logged, and also manually recorded onto data sheets. The testing scope will also include collection and analysis of samples from process input and output 
streams for selected test conditions, and post-test cleanout, inspection, and sampling. Two different test series are planned:

- An initial parametric evaluation of operating conditions will be performed, within reasonable ranges defined by the process and test objectives. This evaluation will enable the operators to determine how to operate each subsystem within target ranges, and in some cases determine what those ranges are.

- Following the initial parametric evaluation, a selected number of operating conditions will be defined for longer-term operation, process measurements, and process sampling to meet test objectives.

When the melt level is high enough to start glass pouring, at any time during this test series, glass pouring will be initiated. Glass pouring is typically semi-continuous, starting and stopping to maintain the melt height within acceptable limits in the melter.

\subsubsection{Initial Parametric Test Series}

Following simulant feed startup, ranges of operation will be determined in sequence. Depending on expediency during the test, the sequence and duration of each of these parametric evaluations may be varied.

- Demonstrate operation at the target induction frequency of $1.6 \mathrm{MHz}$

- Determine maximum feedrate and maximum melter power levels, with minimum melt agitation (no stirring or bubbling). These two evaluations may be done in sequence or simultaneously, as the maximum feedrate cannot be achieved until the melter power is maximized and tuned to the melt conditions. The maximum feedrate for each power level and tuning condition is reached when the cold cap of unmelted feed material covers most (perhaps $\sim 80-95 \%$ ) of the melt surface, or when the target melt temperature can no longer be maintained.

- Determine maximum feedrate and maximum melter power levels.

- Determine the range of glass melt and melter freeboard temperatures that occur under the different feedrate, power level, and cold cap conditions.

- Determine a representative glass melt temperature location for continued single-point temperature measurement.

- Determine the range of melter off-gas composition that results from the different feedrate, power level, and cold cap conditions.

- Determine the degree to which $\mathrm{NO}_{\mathrm{x}}$ and incompletely oxidized species $\left(\mathrm{THC}, \mathrm{CO}\right.$, and $\left.\mathrm{H}_{2}\right)$ are destroyed, and under what conditions, in the TRC, by varying the operating temperature and stoichiometry of the TRC.

- Demonstrate the new glass tapping system.

A detailed matrix of planned parametric test conditions will be prepared prior to the test, for use during the test. The duration of each of these test evolutions may be less than 1 hour or longer than several hours. The total duration of the initial parametric test series may be up to 40 hours. 
Depending on conditions of, and observations from, the parametric test series, one or more shutdowns may be performed during or after the parametric test series and prior to the long-term test series, to:

- Inspect system components such as the inside of the melter lid and crucible, the melter off-gas duct, the TRC, and the wet scrubber.

- Modify system components.

- Evaluate test results and inspections, perform any corrective actions, and select a few $(\sim 3)$ operating conditions for long-term testing.

If the system is operating well with no apparent need to shut down, and conditions desired for the long-term test series are readily apparent, then operations will continue straight from the parametric test series to the long-term test series without a shut-down.

\subsubsection{Off-gas System Evaluation Test Series}

Operating conditions for the OGSE test series will be based on the results of the parametric test series. High-level target operating conditions have been developed by the Phase II-A test team (Girold 2008) and include:

- Test 1: Nominal stable condition, estimated to best represent nominal larger-scale melter conditions. Glass melt temperature: $1,250^{\circ} \mathrm{C}$. Maximum feedrate to achieve maximum cold cap coverage, with nominal air bubbling $(1-1.5 \mathrm{lpm})$, at power levels determined during the parametric tests to achieve a representative specific feedrate $\left(\mathrm{L} / \mathrm{hr} / \mathrm{m}^{2}\right.$ melt surface area) or average melt residence time. This would be the baseline test condition.

- Test 2: Nominal stable higher temperature condition, to evaluate the impact of slightly higher melt temperatures. Glass melt temperature: $1,300{ }^{\circ} \mathrm{C}$, achieved by adjusting power levels or feedrate, while still maintaining maximum practical cold cap coverage. This test condition will demonstrate if $\mathrm{Cs}$ volatility is increased at the higher melt temperature.

- Test 3: Nominal stable lower feedrate condition, to evaluate impact of less-than-complete cold cap coverage. Glass melt temperature: $1,250^{\circ} \mathrm{C}$. This test condition will demonstrate if Cs volatility is affected by the smaller cold cap. This could result in the higher freeboard gas temperatures, lowest levels of $\mathrm{NO}_{\mathrm{x}}$ and incompletely oxidized gas species in the melter off-gas, and lower dust entrainment.

The duration of each of these test conditions may range from 10 to 20 hours. "Steady-state" will be determined based on how steady the induction power, feedrate, glass temperature, and cold cap become after a stepchange in the power level or feedrate. Small adjustments to either power levels or feedrate may be necessary to maintain a relatively steady state cold cap coverage or melt temperature.

The total operating time, nominally assumed to be 80 hours for test planning, will be limited based on the amount of simulant feed, average feedrate, and test funding budgeted for the test time, considering funding required for all other test program components.

A full set of process and off-gas samples (simulant feed, glass, off-gas, off-gas particulate matter, and scrub solution) will be collected for analysis for each of these test conditions. 


\section{FEED SIMULANT}

Approximately 36 million gallons of high-level radioactive waste (HLW) is stored in underground tanks at the SRS. These wastes are from spent nuclear fuel and target treatment, and contain dissolved salt (dissolved solids) and $8 \%$ undissolved sludge in an alkaline solution which consists mainly of metal hydroxides (mostly Fe, $\mathrm{Al}, \mathrm{Mn}$, and $\mathrm{Ni}$ ). This sludge is the waste that is being processed in the DWPF. Sludge Batch 4 (SB4), which is high-aluminum sludge from the HM process, was processed in the DWPF campaign until November 2008. The ART CCIM team has determined that the ART CCIM tests be performed using a non-radioactive simulant of this SB4 melter feed.

The composition of the SB4 waste simulant is shown in Tables 5-1 and 5-2. The simulant used in the OGSE tests is from Batch 1 of a total of four batches of simulant prepared by Harrell Industries. The analytical compositions of all four batches are shown in Table 5-3.

No radioactive elements are included in this simulant. Lead, a trace-level hazardous metal, has also been excluded, although hazardous metals $\mathrm{Cr}$ and $\mathrm{Ni}$ are included. These elements contribute to the formation of spinel crystals within the glass, thus, it is important for this demonstration that they be included in the simulant.

Nonradioactive $\mathrm{Cs}$ is spiked into the simulant as surrogate for radioactive Cs. The Cs is spiked at a level such that, assuming no frit addition, the $\mathrm{Cs}_{2} \mathrm{O}$ concentration in the glass is $0.5 \mathrm{wt} \%$, which is representative of expected Cs levels.

SRNL has recommended, based on initial results of Phase II-A crucible tests, glass frit 503 R6 (target values shown in Table 5-4) at a waste loading of $46 \%$ (as defined by the total percentage of waste oxides in the glass), as defined by the total percentage of waste oxides in the glass (AREVA, "ART CCIM Phase II-A Project Teleconference", June 3, 2008). The actual measured composition of the glass frit is shown compared to the target values in Table 5-5.

The goal of the frit composition and waste loading is to (a) produce a glass with acceptable waste form performance, with minimal nephelene formation (with a nephelene discriminator value, $\left.\mathrm{SiO}_{2} /\left(\mathrm{SiO}_{2}+\mathrm{Na}_{2} \mathrm{O}+\mathrm{Al}_{2} \mathrm{O}_{3}\right),>0.62\right)$, and (b) suitable melter operability, with a liquidus temperature at least $50^{\circ} \mathrm{C}$ less than the planned melter operating temperature to minimize spinel formation in the melter (Marra, Jim, et al, "Formulation Development and Testing for Cold Crucible Induction Melter Technology Retrofit and Deployment Project: Lab-scale Evaluation and Assessment," 2008 Mid-year review, May 29, 2008).

Table 5-6 shows the calculated composition of the feed slurry including the Frit 503 R6 for a waste loading of $46 \%$ oxides in the product glass.

Table 5-7 shows the calculated composition of the product glass including the Frit 503 R6 for a waste loading of $46 \%$ oxides in the product glass, compared to a measured composition for a glass made from the surrogate during laboratory testing with a nearly identical waste loading of $45 \%$.

Melter startup glass frit was prepared and provided for testing so that the startup glass had a composition similar to the intended product glass from the OGSE tests. The composition of the startup glass is shown in Table 5-8. 
Table 5-1. Composition of the calcined solids for the simulant for Sludge Batch 4 (no frit).

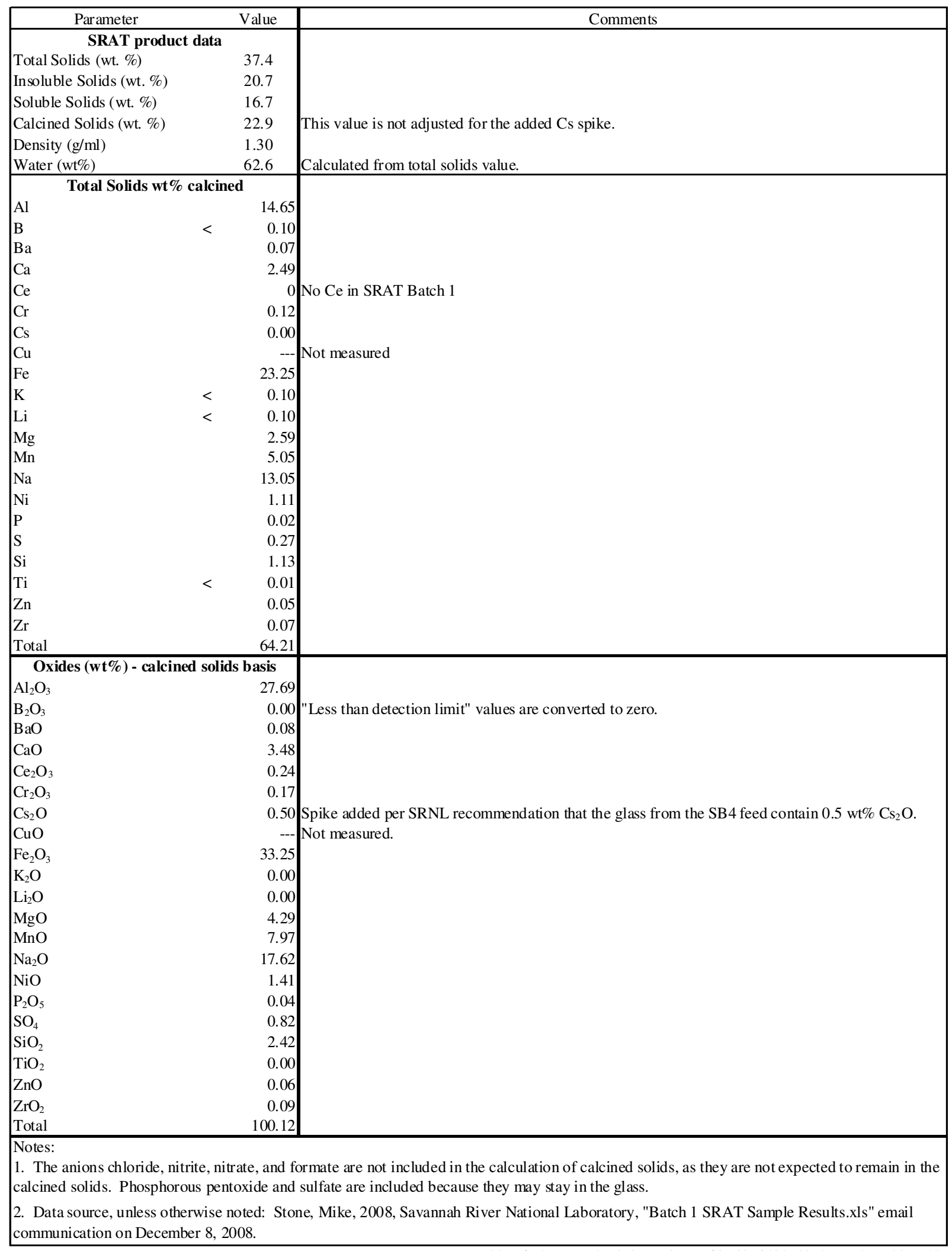

[CCIM feed comp and emissions estimates, frit 503R6 23dec08.xls]test plan calcine table 
Table 5-2. SB4 simulant composition normalized to feed composition basis (no frit).

\begin{tabular}{|c|c|c|c|}
\hline Parameter & Units & Value & Comments \\
\hline Total Solids & $\mathrm{gm} / \mathrm{L}$ & 486 & \\
\hline Insoluble Solids & $\mathrm{gm} / \mathrm{L}$ & 270 & \\
\hline Soluble Solids & $\mathrm{gm} / \mathrm{L}$ & 217 & \\
\hline Calcined Solids & $\mathrm{gm} / \mathrm{L}$ & 298 & $\begin{array}{l}\text { solids because the hydroxides and nitrates are } \\
\text { converted to oxides. }\end{array}$ \\
\hline Density (g/ml) & $\mathrm{gm} / \mathrm{ml}$ & 1.30 & \\
\hline $\mathrm{pH}$ & --- & 6.70 & \\
\hline Water content & $\mathrm{gm} / \mathrm{L}$ & 814 & Calculated from the density and total solids content. \\
\hline Cations & & & \multirow{23}{*}{ Not measured } \\
\hline $\mathrm{Al}$ & $\mathrm{gm} / \mathrm{L}$ & 43.61 & \\
\hline B & $\mathrm{gm} / \mathrm{L}<$ & 0.30 & \\
\hline $\mathrm{Ba}$ & $\mathrm{gm} / \mathrm{L}$ & 0.22 & \\
\hline $\mathrm{Ca}$ & $\mathrm{gm} / \mathrm{L}$ & 7.40 & \\
\hline $\mathrm{Ce}$ & $\mathrm{gm} / \mathrm{L}$ & 0.00 & \\
\hline $\mathrm{Cr}$ & $\mathrm{gm} / \mathrm{L}$ & 0.35 & \\
\hline Cs & $\mathrm{gm} / \mathrm{L}$ & 0.00 & \\
\hline $\mathrm{Cu}$ & $\mathrm{gm} / \mathrm{L}$ & & \\
\hline $\mathrm{Fe}$ & $\mathrm{gm} / \mathrm{L}$ & 69.21 & \\
\hline K & $\mathrm{gm} / \mathrm{L}<$ & 0.30 & \\
\hline $\mathrm{Li}$ & $\mathrm{gm} / \mathrm{L}<$ & 0.30 & \\
\hline $\mathrm{Mg}$ & $\mathrm{gm} / \mathrm{L}$ & 7.69 & \\
\hline $\mathrm{Mn}$ & $\mathrm{gm} / \mathrm{L}$ & 15.02 & \\
\hline $\mathrm{Na}$ & $\mathrm{gm} / \mathrm{L}$ & 38.85 & \\
\hline $\mathrm{Ni}$ & $\mathrm{gm} / \mathrm{L}$ & 3.30 & \\
\hline $\mathrm{P}$ & $\mathrm{gm} / \mathrm{L}$ & 0.05 & \\
\hline S & $\mathrm{gm} / \mathrm{L}$ & 0.81 & \\
\hline $\mathrm{Si}$ & $\mathrm{gm} / \mathrm{L}$ & 3.36 & \\
\hline $\mathrm{Ti}$ & $\mathrm{gm} / \mathrm{L}$ & 0.03 & \\
\hline $\mathrm{Zn}$ & $\mathrm{gm} / \mathrm{L}$ & 0.14 & \\
\hline $\mathrm{Zr}$ & $\mathrm{gm} / \mathrm{L}$ & 0.20 & \\
\hline Total & $\mathrm{gm} / \mathrm{L}$ & 191.14 & \\
\hline \multicolumn{4}{|l|}{ Anions } \\
\hline Fluoride & $\mathrm{gm} / \mathrm{L}<$ & 0.13 & \\
\hline Chloride & $\mathrm{gm} / \mathrm{L}$ & 7.93 & \\
\hline Nitrite & $\mathrm{gm} / \mathrm{L}$ & 7.97 & \\
\hline Nitrate & $\mathrm{gm} / \mathrm{L}$ & 49.66 & \\
\hline $\mathrm{P} 2 \mathrm{O} 5$ & $\mathrm{gm} / \mathrm{L}<$ & 0.13 & \\
\hline Formate $(\mathrm{COOH})$ & $\mathrm{gm} / \mathrm{L}$ & 90.74 & \\
\hline Sulfate & $\mathrm{gm} / \mathrm{L}$ & 1.35 & \\
\hline Oxalate (C2O4) & $\mathrm{gm} / \mathrm{L}<$ & 0.13 & \\
\hline
\end{tabular}


Table 5-3. Sludge Batch 4 waste simulant fabricated by Harrell Industries, Inc. analytical results (from file "SB4 Waste Surrogate Frit 5-3-R6 and Startup Frit Analysis Tables.doc." email communication from E. Tchemitcheff, January 7, 2009).

\begin{tabular}{|c|c|c|c|c|c|}
\hline & Batch 1 & Batch 2 & Batch 3 & Batch 4 & $\begin{array}{c}\text { Combined } \\
\text { Average }\end{array}$ \\
\hline \multicolumn{6}{|c|}{ Elemental wt \% - Calcined at 1,100 deg C } \\
\hline $\mathrm{Al}$ & 14.7 & 14.5 & 12.6 & 15.2 & 14.1 \\
\hline $\mathrm{Ba}$ & 0.07 & 0.07 & 0.06 & 0.0777 & 0.0711 \\
\hline $\mathrm{Ca}$ & 2.49 & 2.62 & 2.51 & 2.09 & 2.45 \\
\hline $\mathrm{Ce}$ & $<0.100$ & $<0.100$ & $<0.100$ & $<0.100$ & \\
\hline $\mathrm{Cr}$ & 0.1 & 0.1 & 0.1 & 0.1 & 0.1 \\
\hline $\mathrm{Cu}$ & $<0.100$ & 0.031 & 0.022 & 0.031 & 0.028 \\
\hline $\mathrm{Fe}$ & 23.3 & 20.3 & 20.0 & 22.1 & 21.3 \\
\hline $\mathrm{K}$ & $<0.100$ & 0.062 & 0.082 & 0.068 & 0.071 \\
\hline $\mathrm{Mg}$ & 2.59 & 3.32 & 3.12 & 2.73 & 2.96 \\
\hline $\mathrm{Mn}$ & 5.0 & 4.6 & 4.9 & 4.9 & 4.8 \\
\hline $\mathrm{Na}$ & 13.1 & 14.9 & 17.2 & 12.9 & 14.6 \\
\hline $\mathrm{Ni}$ & 1.11 & 1.29 & 1.27 & 1.42 & 1.26 \\
\hline $\mathrm{P}$ & 0.018 & 0.013 & 0.012 & 0.012 & 0.0 \\
\hline $\mathrm{S}$ & 0.273 & 0.316 & 0.356 & 0.280 & 0.308 \\
\hline $\mathrm{Si}$ & 1.13 & 1.36 & 1.14 & 1.40 & 1.24 \\
\hline $\mathrm{Ti}$ & $<0.100$ & $<0.100$ & $<0.100$ & $<0.100$ & \\
\hline $\mathrm{Zn}$ & 0.0455 & 0.0435 & 0.0413 & 0.0457 & 0.0438 \\
\hline $\mathrm{Zr}$ & 0.0685 & 0.0644 & 0.0604 & 0.0648 & 0.0645 \\
\hline \multicolumn{6}{|c|}{ Anions - mg/kg slurry } \\
\hline $\mathrm{F}$ & $<100$ & $<100$ & $<100$ & $<100$ & \\
\hline $\mathrm{Cl}$ & 6100 & 6670 & 6920 & 6220 & 6500 \\
\hline $\mathrm{NO}_{2}$ & 6130 & 6160 & 2600 & 2870 & 4580 \\
\hline $\mathrm{NO}_{3}$ & 38200 & 35000 & 44600 & 33700 & 38300 \\
\hline $\mathrm{PO}_{4}$ & $<100$ & $<100$ & $<100$ & $<100$ & \\
\hline $\mathrm{HCO}_{2}$ & 69800 & 71000 & 74100 & 70000 & 71300 \\
\hline $\mathrm{SO}_{4}$ & 1040 & 1330 & 1550 & 1110 & 1270 \\
\hline $\mathrm{C}_{2} \mathrm{O}_{4}$ & $<100$ & $<100$ & $<100$ & $<100$ & \\
\hline \multicolumn{6}{|c|}{ Solids - wt \% } \\
\hline Total & 37.4 & 35.5 & 34.8 & 37 & 36.1 \\
\hline Insoluble & 20.6 & 18.6 & 16.3 & 20.6 & 18.9 \\
\hline Soluble & 16.8 & 16.9 & 18.5 & 16.4 & 17.2 \\
\hline Calcined & 22.9 & 21.3 & 20 & 22.7 & 21.6 \\
\hline $\mathrm{pH}$ & 6.7 & 6.95 & 6.62 & 6.5 & \\
\hline $\begin{array}{c}\text { Density } \\
(\mathrm{g} / \mathrm{ml})\end{array}$ & 1.30 & 1.28 & 1.27 & 1.30 & 1.29 \\
\hline
\end{tabular}


Table 5-4. Frit 503-R6 composition for the ART CCIM Phase II-A demonstration tests.

\begin{tabular}{|l|c|c|}
\hline \multicolumn{1}{|c|}{ Oxide } & wt\% (dry basis) & Particle density, gm/cm \\
\hline $\mathrm{B}_{2} \mathrm{O}_{3}$ & 14 & 1.85 \\
$\mathrm{Li}_{2} \mathrm{O}$ & 9 & 2.01 \\
$\mathrm{Na}_{2} \mathrm{O}$ & 3 & 2.27 \\
$\mathrm{SiO}_{2}$ & 74 & 2.2 \\
$\mathrm{Total}_{\text {alaverage }}$ & 100 & 2.14 \\
\hline Notes: \\
1. Source of Frit 503R6 composition: Marra, Jim, et al, "Glass Formulation \\
Development and Testing for Cold Crucible Induction Melter Technology Retrofit and \\
Deployment Project, Phase II-A - Demonstrations, Lab-Scale Evaluation and \\
Assessment Final Report," Draft, SRNS-STI-2008-00036, August xx, 2008. \\
2. The frit particle density was estimated using the weighted averages of the pure \\
constituent particle densities.
\end{tabular}

[CCIM feed comp and emissions estimates, frit 503 R6 26sept08.xls]frit composition

Table 5-5. Glass frit 503-R6 analytical results (from file "SB4 Waste Surrogate Frit 5-3-R6 and Startup Frit Analysis Tables.doc." email communication from E. Tchemitcheff, January 7, 2009).

\begin{tabular}{|c|c|c|c|c|c|}
\hline Oxide & $\begin{array}{l}\text { Target } \\
\text { (wt \%) }\end{array}$ & $\begin{array}{c}1^{\text {st }} \text { Sample, } \\
1^{\text {st }} \text { Analyses } \\
\text { (wt \%) }\end{array}$ & $\begin{array}{c}1^{\text {st }} \text { Sample, } 2^{\text {nd }} \\
\text { Analyses } \\
\text { (wt \%) }\end{array}$ & $\begin{array}{c}2^{\text {nd }} \text { Sample, } \\
\text { 1st Analyses } \\
(\text { wt \%) }\end{array}$ & $\begin{array}{c}\text { Average } \\
\text { (wt \%) }\end{array}$ \\
\hline $\mathrm{B}_{2} \mathrm{O}_{3}$ & 14 & 13.37 & 13.10 & 13.03 & 13.17 \\
\hline $\mathrm{Na}_{2} \mathrm{O}$ & 3 & 3.79 & 3.87 & 3.78 & 3.81 \\
\hline $\mathrm{Li}_{2} \mathrm{O}$ & 9 & 8.67 & 8.53 & 8.50 & 8.57 \\
\hline $\mathrm{SiO}_{2}$ & 74 & 72.76 & 73.06 & 73.30 & 73.04 \\
\hline Impurities & & 1.41 & 1.44 & 1.39 & 1.41 \\
\hline $\mathrm{Al}_{2} \mathrm{O}_{3}$ & & 1.06 & 1.09 & 1.05 & 1.07 \\
\hline $\mathrm{CaO}$ & & 0.15 & 0.15 & 0.16 & 0.15 \\
\hline $\mathrm{Cr}_{2} \mathrm{O}_{3}$ & & 0.02 & - & - & - \\
\hline $\mathrm{Fe}_{2} \mathrm{O}_{3}$ & & 0.11 & 0.12 & 0.10 & 0.11 \\
\hline $\mathrm{MgO}$ & & 0.02 & 0.02 & 0.02 & 0.02 \\
\hline $\mathrm{TiO}_{2}$ & & 0.05 & 0.06 & 0.06 & 0.06 \\
\hline Total & 100 & 100.00 & 100.00 & 100.00 & 100.00 \\
\hline
\end{tabular}


Table 5-6. Calculated composition of simulant SB4 feed slurry including glass frit 503 R6.

\begin{tabular}{|c|c|c|c|}
\hline Parameter & Units & Value & Comments \\
\hline Waste loading & $\begin{array}{l}\text { mass calcine/(mass } \\
\text { calcine }+ \text { frit })\end{array}$ & $46 \%$ & wt $\%$ of waste oxides in the glass \\
\hline Ratio, frit add per calcine & & 1.17 & \\
\hline Added Frit 503R6 & gm/L neat SRAT & 349 & The mass of added frit was calculated at the specified waste \\
\hline Added Frit 503R6 & $\mathrm{cm}^{3} / \mathrm{L}$ neat SRAT & 164 & loading in the glass. \\
\hline Added Frit 503R6 & gm/L feed slurry & 300 & \\
\hline $\begin{array}{l}\text { Vol feed slurry/ vol } \\
\text { SRAT product }\end{array}$ & $\begin{array}{l}\text { L slurry/ L neat } \\
\text { SRAT }\end{array}$ & 1.16 & Calculated assuming no frit dissolves into the solution. \\
\hline Total Solids & gm/L slurry & 718 & \\
\hline Total Solids & wt\% & $50.7 \%$ & \\
\hline Insoluble Solids & gm/L slurry & 532 & Assume no frit dissolves. \\
\hline Soluble Solids & gm/L slurry & 186 & \\
\hline Calcined Solids (Glass) & gm/L slurry & 556 & $\begin{array}{l}\text { The mass of calcined solids is different from total solids } \\
\text { because the hydroxides and nitrates are converted to oxides. }\end{array}$ \\
\hline Calcined Solids (Glass) & kg glass/kg slurry & 0.392 & \\
\hline Density $(\mathrm{g} / \mathrm{ml})$ & gm/ml slurry & 1.42 & Calculated assuming no frit dissolves into the solution. \\
\hline $\mathrm{pH}$ & --- & 6.70 & \\
\hline Water content & gm/L slurry & 699 & \\
\hline \multicolumn{3}{|l|}{ Cations } & \multirow{23}{*}{ 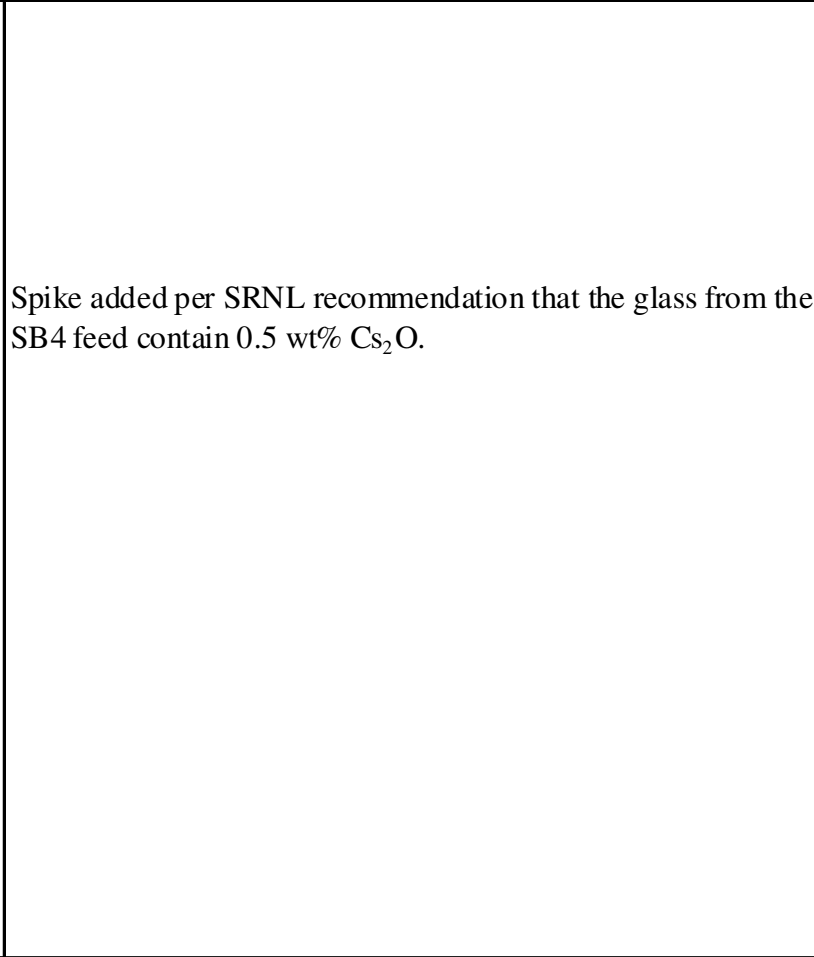 } \\
\hline $\mathrm{Al}$ & gm/L slurry & 37.48 & \\
\hline B & gm/L slurry & 13.30 & \\
\hline $\mathrm{Ba}$ & gm/L slurry & 0.19 & \\
\hline $\mathrm{Ca}$ & gm/L slurry & 6.36 & \\
\hline $\mathrm{Ce}$ & gm/L slurry & 0.00 & \\
\hline $\mathrm{Cr}$ & gm/L slurry & 0.30 & \\
\hline Cs & gm/L slurry & 2.62 & \\
\hline $\mathrm{Cu}$ & gm/L slurry & 0.00 & \\
\hline $\mathrm{Fe}$ & gm/L slurry & 59.48 & \\
\hline $\mathrm{K}$ & gm/L slurry & 0.26 & \\
\hline $\mathrm{Li}$ & gm/L slurry & 12.81 & \\
\hline $\mathrm{Mg}$ & gm/L slurry & 6.61 & \\
\hline $\mathrm{Mn}$ & gm/L slurry & 12.91 & \\
\hline $\mathrm{Na}$ & $\mathrm{gm} / \mathrm{L}$ slurry & 40.07 & \\
\hline $\mathrm{Ni}$ & gm/L slurry & 2.84 & \\
\hline $\mathrm{P}$ & gm/L slurry & 0.04 & \\
\hline$S$ & gm/L slurry & 0.70 & \\
\hline $\mathrm{Si}$ & gm/L slurry & 106.80 & \\
\hline $\mathrm{Ti}$ & gm/L slurry & 0.03 & \\
\hline $\mathrm{Zn}$ & $\mathrm{gm} / \mathrm{L}$ slurry & 0.12 & \\
\hline $\mathrm{Zr}$ & gm/L slurry & 0.18 & \\
\hline Totals & gm/L slurry & 303.08 & \\
\hline \multicolumn{3}{|l|}{ Anions } & \\
\hline Chloride & gm/L slurry & 6.82 & \\
\hline Nitrite & gm/L slurry & 6.85 & \\
\hline Nitrate & gm/L slurry & 42.68 & \\
\hline Formate $(\mathrm{COOH})$ & gm/L slurry & 77.98 & \\
\hline Sulfate & gm/L slurry & 1.16 & \\
\hline \multicolumn{4}{|c|}{$\begin{array}{l}\text { Notes: } \\
\text { 1. The concentrations are normalized to the volume of the frit-added melter feed slurry. } \\
\text { 1. Data sources are tables 5-1 through 5-4. }\end{array}$} \\
\hline
\end{tabular}

[CCIM feed comp and emissions estimates, frit 503R6 23dec08.x 1s]melter feed with frit 
Table 5-7. Calculated product glass composition including glass frit 503 R6.

\begin{tabular}{|c|c|c|c|c|}
\hline \multicolumn{2}{|c|}{ Elemental basis } & \multicolumn{2}{|c|}{ Oxide basis } & \multirow{2}{*}{$\begin{array}{l}\text { Measured glass composition, } 45 \% \\
\text { waste loading from Marra 2008 } \\
\text { wt } \% \\
\end{array}$} \\
\hline Element & wt $\%$ & Oxide & $\mathrm{wt} \%$ & \\
\hline $\mathrm{Al}$ & 6.74 & $\mathrm{Al}_{2} \mathrm{O}_{3}$ & 12.73 & 12.68 \\
\hline B & 2.39 & $\mathrm{~B}_{2} \mathrm{O}_{3}$ & 7.71 & 7.70 \\
\hline $\mathrm{Ba}$ & 0.03 & $\mathrm{BaO}$ & 0.04 & 0.04 \\
\hline $\mathrm{Ca}$ & 1.14 & $\mathrm{CaO}$ & 1.60 & 1.38 \\
\hline $\mathrm{Ce}$ & 0.00 & $\mathrm{Ce}_{2} \mathrm{O}_{3}$ & 0 & 0.11 \\
\hline $\mathrm{Cr}$ & 0.05 & $\mathrm{Cr}_{2} \mathrm{O}_{3}$ & 0.08 & 0.10 \\
\hline Cs & 0.47 & $\mathrm{Cs}_{2} \mathrm{O}$ & 0.50 & --- \\
\hline $\mathrm{Cu}$ & 0.00 & $\mathrm{CuO}$ & 0 & 0.03 \\
\hline $\mathrm{Fe}$ & 10.70 & $\mathrm{Fe}_{2} \mathrm{O}_{3}$ & 15.30 & 14.42 \\
\hline K & 0.05 & $\mathrm{~K}_{2} \mathrm{O}$ & 0.06 & 0.03 \\
\hline $\mathrm{Li}$ & 2.30 & $\mathrm{Li}_{2} \mathrm{O}$ & 4.96 & 5.50 \\
\hline Mg & 1.19 & $\mathrm{MgO}$ & 1.97 & 1.38 \\
\hline Mn & 2.32 & $\mathrm{MnO}$ & 3.00 & 2.88 \\
\hline $\mathrm{Na}$ & 7.20 & $\mathrm{Na}_{2} \mathrm{O}$ & 9.71 & 10.40 \\
\hline $\mathrm{Ni}$ & 0.51 & $\mathrm{NiO}$ & 0.65 & 0.83 \\
\hline $\mathrm{P}$ & 0.01 & $\mathrm{P}_{2} \mathrm{O}_{5}$ & 0.02 & --- \\
\hline S & 0.13 & $\mathrm{SO}_{4}$ & 0.38 & 0.43 \\
\hline $\mathrm{Si}$ & 19.20 & $\mathrm{SiO}_{2}$ & 41.07 & 42.05 \\
\hline $\mathrm{Ti}$ & 0.00 & $\mathrm{TiO}_{2}$ & 0.01 & 0.03 \\
\hline $\mathrm{Zn}$ & 0.02 & $\mathrm{ZnO}$ & 0.03 & 0.03 \\
\hline $\mathrm{Zr}$ & 0.03 & $\mathrm{ZrO}_{2}$ & 0.04 & 0.05 \\
\hline Total & 54.50 & Total & 99.84 & 100.03 \\
\hline \multicolumn{5}{|c|}{$\begin{array}{l}\text { Notes: } \\
\text { 1. No volatilization of any elements is assumed. } \\
\text { 2. No anions are included in this calculation. }\end{array}$} \\
\hline
\end{tabular}

[CCIM feed comp and emissions estimates, frit 503R6 23dec08.xls]glass with frit 
Table 5-8. Startup glass (503-R6/SB4 at $46 \mathrm{wt} \%$ waste loading) analytical results (from file "SB4 Waste Surrogate Frit 5-3-R6 and Startup Frit Analysis Tables.doc." email communication from E. Tchemitcheff, January 7, 2009).

\begin{tabular}{|c|c|c|}
\hline Oxide & $\begin{array}{c}\text { Target } \\
\text { (wt \%) }\end{array}$ & $\begin{array}{c}\mathbf{2}^{\text {nd }} \text { Sample } \\
\text { (wt \%) }\end{array}$ \\
\hline $\mathrm{Al}_{2} \mathrm{O}_{3}$ & $12.96 \pm 1.0$ & 13.1 \\
\hline $\mathrm{B}_{2} \mathrm{O}_{3}$ & $7.56 \pm 0.8$ & 7.03 \\
\hline $\mathrm{BaO}$ & $0.02-0.1$ & 0.00 \\
\hline $\mathrm{CaO}$ & $1.40 \pm 0.5$ & 1.39 \\
\hline $\mathrm{Ce}_{2} \mathrm{O}_{3}$ & $0.05-0.15$ & 0.00 \\
\hline $\mathrm{Cr}_{2} \mathrm{O}_{3}$ & $0.05-0.15$ & 0.021 \\
\hline $\mathrm{CuO}^{2} \mathrm{Fe}_{2} \mathrm{O}_{3}$ & $0.02-0.1$ & 0.035 \\
\hline $\mathrm{K}_{2} \mathrm{O}$ & $0.02-0.1$ & 13.0 \\
\hline $\mathrm{Li}_{2} \mathrm{O}$ & $4.86 \pm 0.5$ & 0.103 \\
\hline $\mathrm{MgO}$ & $1.41 \pm 0.5$ & 5.20 \\
\hline $\mathrm{MnO}$ & $2.94 \pm 0.5$ & 0.927 \\
\hline $\mathrm{Na}_{2} \mathrm{O}$ & $11.13 \pm 1.0$ & 3.01 \\
\hline $\mathrm{NiO}_{\mathrm{SOO}}$ & $0.5-1.0$ & 11.2 \\
\hline $\mathrm{SO}_{4}$ & $0.2-0.8$ & 0.586 \\
\hline $\mathrm{SiO}$ & $41.34 \pm 2.0$ & 0.098 \\
\hline $\mathrm{ZnO}$ & $0.02-1.0$ & 43.7 \\
\hline $\mathrm{ZrO}$ & $0.02-1.0$ & 0.03 \\
\hline $\mathrm{PbO}_{2}$ & 0 & 0.476 \\
\hline $\mathrm{Total}$ & & 0.015 \\
\hline & & 99.9 \\
\hline
\end{tabular}

\section{MEASUREMENTS, SAMPLE COLLECTION, AND SAMPLE ANALYSIS}

Diagnostic activities performed during CCIM tests include (a) continuous process measurements including key process flowrates, temperatures, and pressures, (b) continuous process gas composition measurements, and (c) sample collection for laboratory analysis. These diagnostic activities provide on-line data for controlling the process within test acceptance limits, samples for post-test analysis, and data for mass balance calculations to determine the fate of feed constituents.

\subsection{Process Measurements}

Process monitoring, process control, and data collection is performed primarily by the Data Acquisition and Control System (DACS) that continuously and automatically monitors and controls key system components and electronically logs key data. Process data that is not electronically logged by this system is periodically recorded manually on operator data sheets. Manual control of many process parameters is also done according to operator discretion, the test plan, and CCIM test system operating instructions.

Table 6-1 shows key process data that is electronically logged by the DACS and manually logged on operator data sheets. 


\subsection{Continuous Emissions Monitoring System (CEMS)}

The CEMS is a component of the process monitoring and control system. The CEMS continuously samples and analyses the off-gas for major constituents, such as $\mathrm{O}_{2}, \mathrm{CO}_{2}, \mathrm{CO}, \mathrm{NO}_{\mathrm{x}}$, and Total Hydrocarbons (THC). The actual suite of gas speciation depends on test objectives. The location in the off-gas control system where the gas is sampled for analysis also depends on the test objectives. Locations may include the melter outlet, the outlet of the Thermal Reaction Chamber, downstream of the WESP, or downstream of the ID fan. The CEMS includes the following components:

- Sample probe

- Sample gas filter

- Sample gas chiller

- Sample pump

- Sample gas analyzers

- Calibration gases and regulators

- Tubing, valving, flowmeters, and distributors for calibration gas and sample gas

- Communication with the Process Monitoring and Control System for data recording

The CEMS (shown in Figure 6-1) will be used to sample and analyze the melter outlet gas at the sample location downstream of the melter outlet duct. This CEMS is configured to measure process gas composition at the melter outlet upstream of the TRC, before the process gas is fully oxidized.

A heated sample probe is used to continuously extract a portion of the off-gas from the off-gas pipe. A heated filter at the back end of the heated probe removes particulate matter from the sample gas. The sample gas flows under negative pressure from the probe through a sample line to the chiller system.

The chiller system cools the sample gas and removes moisture. The sample gas is analyzed on a dry basis because the chiller removes moisture from the sample gas.

Some of the water-soluble gases like $\mathrm{NO}_{2}$ and $\mathrm{HCl}$, and some higher molecular weight or water-soluble hydrocarbons, if present, could be captured with the water condensate. If so, those amounts of condensed or scrubbed gases would not be detected by the analyzers. Two actions are done to minimize and quantify loss of soluble/condensable gas species. First, the chiller system is designed according to United States Environmental Protection Agency (US EPA) guidance (40 CFR 60 Appendix A Method 6C) to minimize acid gas scrubbing. Second, condensate samples are collected for analysis as a quality assurance check to determine amounts, if any, of condensed or scrubbed species. Results of these analyses from prior tests have shown negligible organic, $\mathrm{NO}_{\mathrm{x}}$, and other acid gas scrubbing. 
ART CCIM Phase II-A

INL/EXT-0814449

Off-gas System Evaluation Test Plan

Table 6-1. Key process data that is electronically or manually logged.

\begin{tabular}{|c|c|c|c|c|}
\hline Parameter & Units & Instrument & $\begin{array}{c}\text { DACS tag } \\
\text { name }\end{array}$ & Comments \\
\hline \multicolumn{5}{|l|}{ Feed system: } \\
\hline \multicolumn{5}{|l|}{ Simulant feedrate } \\
\hline Simulant feed tank height & Inches & --- & --- & Manual record only \\
\hline Simulant density & $\mathrm{gm} / \mathrm{ml}$ & & & \\
\hline Simulant composition & --- & --- & --- & $\begin{array}{l}\text { Determined at time of simulant prep from } \\
\text { recipe; verified by sample analysis }\end{array}$ \\
\hline $\begin{array}{l}\text { Composition, each simulant } \\
\text { additive }\end{array}$ & --- & --- & --- & $\begin{array}{l}\text { Use vendor-provided composition unless } \\
\text { sample analysis is required }\end{array}$ \\
\hline \multicolumn{5}{|l|}{ RF Generator cooling system: } \\
\hline \multicolumn{5}{|l|}{ Primary cooling water flowrate } \\
\hline Primary cooling water inlet temp & ${ }^{\circ} \mathrm{C}$ & Type K TC & & \\
\hline Primary cooling water outlet temp & ${ }^{\circ} \mathrm{C}$ & Type K TC & & \\
\hline Primary cooling water pressure & psig & & & \\
\hline \multicolumn{5}{|l|}{ Secondary flowrate } \\
\hline Secondary inlet temp & ${ }^{\circ} \mathrm{C}$ & Type K TC & & \\
\hline Secondary outlet temp & ${ }^{\circ} \mathrm{C}$ & Type K TC & & \\
\hline Secondary pressure & psig & & & \\
\hline \multicolumn{5}{|l|}{ Induction coil cooling system: } \\
\hline \multicolumn{5}{|l|}{ Primary cooling water flowrate } \\
\hline Primary cooling water inlet temp & ${ }^{\circ} \mathrm{C}$ & Type K TC & & \\
\hline Primary cooling water outlet temp & ${ }^{\circ} \mathrm{C}$ & Type K TC & & \\
\hline Primary cooling water pressure & psig & & & \\
\hline \multicolumn{5}{|l|}{ Secondary flowrate } \\
\hline Secondary inlet temp & ${ }^{\circ} \mathrm{C}$ & Type K TC & & \\
\hline Secondary outlet temp & ${ }^{\circ} \mathrm{C}$ & Type K TC & & \\
\hline Secondary pressure & psig & & & \\
\hline \multicolumn{5}{|l|}{ Crucible cooling system: } \\
\hline \multicolumn{5}{|l|}{ Primary cooling water flowrate } \\
\hline Primary cooling water inlet temp & ${ }^{\circ} \mathrm{C}$ & Type K TC & & \\
\hline Primary cooling water outlet temp & ${ }^{\circ} \mathrm{C}$ & Type K TC & & \\
\hline Primary cooling water pressure & psig & & & \\
\hline \multicolumn{5}{|l|}{ Secondary flowrate } \\
\hline Secondary inlet temp & ${ }^{\circ} \mathrm{C}$ & Type K TC & & \\
\hline Secondary outlet temp & ${ }^{\circ} \mathrm{C}$ & Type K TC & & \\
\hline Secondary pressure & psig & & & \\
\hline \multicolumn{5}{|l|}{ Generator/crucible system: } \\
\hline Induction voltage & $\mathrm{V}$ & & & \\
\hline Induction current & $\mathrm{A}$ & & & \\
\hline Induction power & $\mathrm{kW}$ & & & \\
\hline Bubbler air flowrate & scfm & --- & --- & Manual record from rotameter \\
\hline Bubbler dP & in $\mathrm{H}_{2} \mathrm{O}$ & & & \\
\hline Glass melt temp & ${ }^{\circ} \mathrm{C}$ & Type K TC & & \\
\hline Crucible interior wall temp & ${ }^{\circ} \mathrm{C}$ & Type K TC & & \\
\hline Tapper temp & ${ }^{\circ} \mathrm{C}$ & Type K TC & & \\
\hline Glass basin weight & $\mathrm{kg}$ & Weigh scale & --- & Manual record \\
\hline Freeboard temp & ${ }^{\circ} \mathrm{C}$ & Type K TC & & \\
\hline Freeboard interior wall temp & ${ }^{\circ} \mathrm{C}$ & Type K TC & & \\
\hline Freeboard pressure & in. $\mathrm{H}_{2} \mathrm{O}$ & & & \\
\hline
\end{tabular}


Table 6-1. Key process data that is electronically or manually logged (continued).

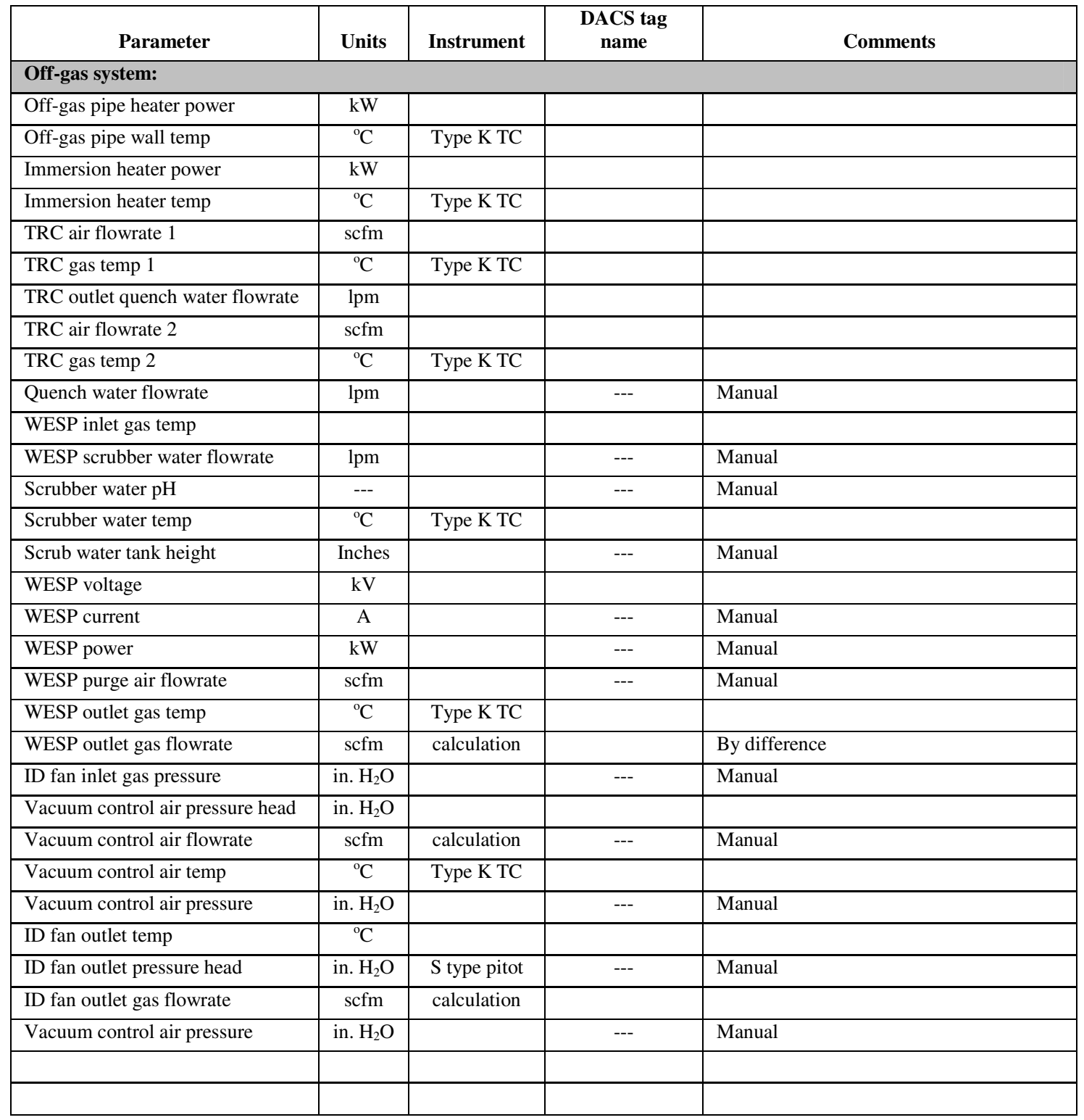

All components downstream of the sample gas chiller system are unheated because condensable moisture is removed in the chiller. The sample pump induces the negative pressure needed to draw the sample gas from the off-gas pipe into the CEMS. A backup filter located immediately downstream of the sample pump provides added protection for the flow meters and analyzers from particulate matter damage or fouling.

Total hydrocarbon (THC) analysis is made by flame ionization detection of $\mathrm{C}$ ions that are produced when hydrocarbon compounds are ionized at high temperatures in a hydrogen-air flame.

The components of the sample pump, and all other components of the CEMS that contact the sample gas, are constructed of stainless steel, Teflon, glass, or other materials designed to avoid reaction with the sample gas. 


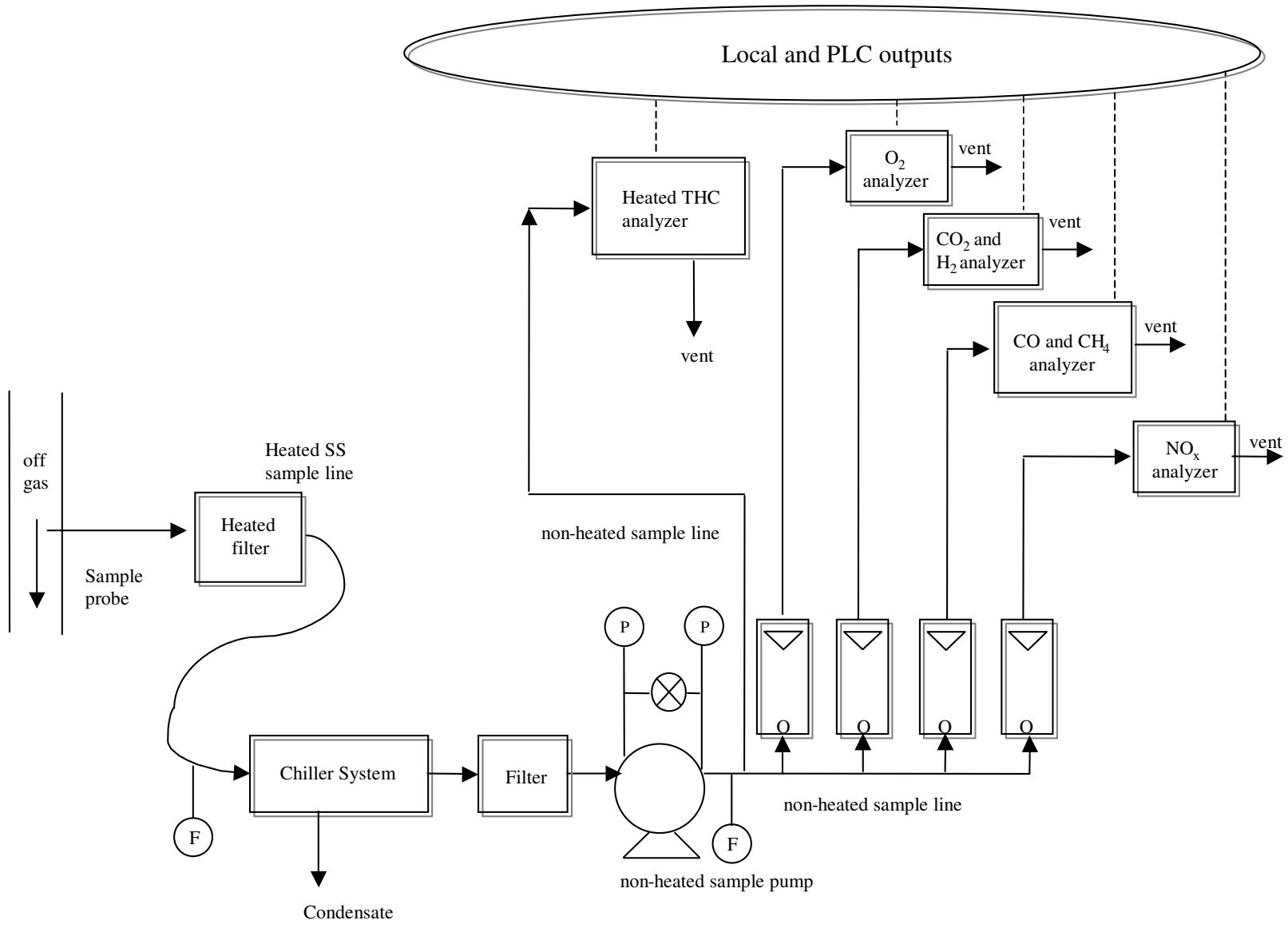

Figure 6-1. CEMS for INL CCIM process gas measurements at the melter outlet sample location.

Specifications for the gas analyzers are shown in Table 6-2. The analyzers are calibrated with calibration gases before, during, and after each test series. The actual calibration frequency is determined considering calibration error and calibration drift that the CEMS incurs during each test, and considering the schedule for test activities when the analyzers need to be on-line for key test periods. Past experience has shown that CEMS calibrations once per day or even less frequent are usually adequate. During each calibration, the following activities are generally performed:

- The system is leak-checked two ways (a) by checking the response of the $\mathrm{O}_{2}$ analyzer (a significant $\mathrm{O}_{2}$ response would indicate a significant amount of air inleakage in the CEMS upstream of the sample pump), and (b) by running the sample pump with the CEMS inlet plugged and demonstrating no sample gas flow.

- Analyzer zero responses are determined using a zero gas $\left(\mathrm{N}_{2}\right.$ gas for all of the analyzers, or $\mathrm{N}_{2}$ for the $\mathrm{O}_{2}$ analyzer and air for the other analyzers).

- Analyzer span responses are determined using a calibration gas with the specified gas concentration.

- Calibration data generated prior to any analyzer adjustments applies to CEMS data during the time period prior to the calibration; calibration data generated after analyzer adjustments applies to CEMS data during the time period following that calibration. 
Table 6-2. Typical analyzers used in the continuous emission monitoring (CEM) systems.

\begin{tabular}{|c|c|c|c|c|c|c|c|c|}
\hline \multirow{2}{*}{$\begin{array}{l}\text { Gas } \\
\text { species }\end{array}$} & \multirow[b]{2}{*}{ Instrument } & \multirow[b]{2}{*}{ Detection principle } & \multirow{2}{*}{$\begin{array}{l}\text { Instrument } \\
\text { range }\end{array}$} & \multicolumn{4}{|c|}{ Acceptance limits, \% FS } & \multirow{2}{*}{$\begin{array}{l}\text { Reference } \\
\text { method }\end{array}$} \\
\hline & & & & Calibration & Drift & Linearity & Bias & \\
\hline \multirow[t]{2}{*}{$\mathrm{O}_{2}$} & $\begin{array}{l}\text { Servomex } 1440 \\
\text { CEMS 1) }\end{array}$ & Paramagnetism & \multirow[t]{2}{*}{0 to $25 \%$} & \multirow[t]{3}{*}{2} & \multirow[t]{3}{*}{3} & \multirow[t]{3}{*}{4} & \multirow[t]{3}{*}{5} & \multirow{3}{*}{$\begin{array}{l}40 \text { CFR } 60 \\
\text { App. A } \\
\text { Method 3A }\end{array}$} \\
\hline & $\begin{array}{l}\text { In situ } \mathrm{ZrO}_{2} \text { probe } \\
\text { (CEMS 2) }\end{array}$ & Electrochemical & & & & & & \\
\hline $\mathrm{CO}_{2}$ & $\begin{array}{l}\text { Nova 4230 RM } \\
\text { (CEMS 1) } \\
\text { CAI (CEMS 2) }\end{array}$ & $\begin{array}{l}\text { Nondispersive infrared } \\
\text { (NDIR) }\end{array}$ & $\begin{array}{l}0 \text { to } 40 \% \\
0 \text { to } 100 \%\end{array}$ & & & & & \\
\hline $\mathrm{H}_{2}$ & $\begin{array}{l}\text { Nova } 4230 \text { RM } \\
\text { (CEMS 1) }\end{array}$ & Thermal conductivity & 0 to $5 \%$ & --- & --- & --- & --- & --- \\
\hline $\mathrm{CO}$ & $\begin{array}{l}\text { CAI 200 (CEMS 1) } \\
\text { CAI (CEMS 2) }\end{array}$ & NDIR & $\begin{array}{l}0 \text { to } 1 \% \\
0 \text { to } 2 \% \\
\text { (CEMS 1) } \\
0-500 \text { ppm } \\
0-2,500 \text { ppm } \\
\text { (CEMS 2) }\end{array}$ & 5 & 10 & 2 & --- & $\begin{array}{l}\text { 40 CFR } 60 \\
\text { App. A } \\
\text { Method } 10\end{array}$ \\
\hline $\mathrm{CH}_{4}$ & CAI 200 (CEMS 1) & & $\begin{array}{l}0 \text { to } 0.5 \% \\
0 \text { to } 1 \%\end{array}$ & --- & --- & --- & --- & --- \\
\hline \multirow[t]{2}{*}{$\begin{array}{l}\mathrm{NO} \\
\mathrm{NO}_{\mathrm{x}}\end{array}$} & $\begin{array}{l}\text { Ametek M922 } \\
\text { (CEMS 1) }\end{array}$ & $\begin{array}{l}\text { Dispersive ultraviolet } \\
\text { (DUV) }\end{array}$ & $0-5,000 \mathrm{ppm}$ & \multirow[t]{2}{*}{2} & \multirow[t]{2}{*}{3} & \multirow[t]{2}{*}{4} & \multirow[t]{2}{*}{5} & \multirow{2}{*}{$\begin{array}{l}\text { 40 CFR } 60 \\
\text { App. A } \\
\text { Method 7E }\end{array}$} \\
\hline & $\begin{array}{l}\text { Ecophysics } \\
\text { CLD 70E (CEMS 2) }\end{array}$ & Chemiluminescence & $\begin{array}{l}0 \text { to } \\
5,000 \mathrm{ppm}\end{array}$ & & & & & \\
\hline THC & $\begin{array}{l}\text { CAI 300 HFID } \\
\text { (CEMS 2) }\end{array}$ & $\begin{array}{l}\text { Flame ionization } \\
\text { detection (FID) }\end{array}$ & $0-3 \% \mathrm{C}_{1}$ & 5 & 3 & --- & --- & $\begin{array}{l}40 \text { CFR } 60 \\
\text { App. A } \\
\text { Method 25A }\end{array}$ \\
\hline $\mathrm{SO}_{2}$ & $\begin{array}{l}\text { Ametek M921 } \\
\text { (CEMS 2) }\end{array}$ & $\begin{array}{l}\text { Nondispersive } \\
\text { ultraviolet (NDUV) }\end{array}$ & $0-100 \mathrm{ppm}$ & 2 & 3 & 4 & 5 & $\begin{array}{l}40 \text { CFR 60 } \\
\text { App. A } \\
\text { Method 6C }\end{array}$ \\
\hline $\mathrm{HCl}$ & $\begin{array}{l}\text { Thermo 15C } \\
\text { (CEMS 2) }\end{array}$ & $\begin{array}{l}\text { NDIR with gas filter } \\
\text { correlation (GFC) }\end{array}$ & $\begin{array}{l}0-100 \mathrm{ppm} \\
\text { to } 0-5,000 \\
\mathrm{ppm}\end{array}$ & --- & --- & --- & --- & --- \\
\hline
\end{tabular}

- For those analyzers which require dilution for operation, the calibration data can be used to generate a composite correction factor for both air dilution and span calibration.

- If the calibrations show that calibrations, drift, linearity, or bias exceed acceptance limits, the CEMS data is corrected following the test.

\subsection{Process Sample Collection and Analysis}

Process sample collection and analysis is required to determine the fate of feed constituents, perform process mass balances, evaluate the properties of the solid and liquid products, and speciate off-gas constituents. Tables 6-3 and 6-4 show the intended process sample collection matrix and estimated number of samples. The sample collection matrix is designed to generate samples of feed, off-gas, and product materials sufficient to characterize those materials, perform key mass balances, and determine the fate of feed constituents in the process.

The more simple analyses (such as $\mathrm{pH}$ and gravimetric analyses) can be done at the INL or its subcontractors. The more complex analyses will be performed by SRNL.

Sample analysis procedures are summarized in Table 6-5. Sample analyses performed by SRNL will be performed using laboratory procedures developed by SRNL for these matrices. 
ART CCIM Phase II-A

INL/EXT-0814449

Off-gas System Evaluation Test Plan

Table 6-3. Sample matrix for the CCIM tests.

\begin{tabular}{|c|c|c|c|c|c|c|}
\hline Sample & Matrix & Container & Frequency & $\begin{array}{l}\text { Estimated number } \\
\text { of samples }\end{array}$ & Analyses & $\mathrm{Lab}$ \\
\hline $\begin{array}{l}\text { Feed } \\
\text { simulant } \\
\text { including } \\
\text { frit }\end{array}$ & $\begin{array}{l}\text { Liquid } \\
\text { slurry }\end{array}$ & $\geq 250 \mathrm{ml} \mathrm{PE}$ & $\begin{array}{l}\text { Once at start of parametric } \\
\text { tests, once at start of the OGSE } \\
\text { test series, and once at end of } \\
\text { the OGSE test series. }\end{array}$ & $\begin{array}{l}3 \text { samples, } 6 \\
\text { containers ( } 1 \text { plus } 1 \\
\text { archive) }\end{array}$ & $\begin{array}{l}\text { pH } \\
\text { Density } \\
\text { TDS } \\
\text { UDS } \\
\text { LOI (calcined solids) } \\
\text { TOC } \\
\text { Elemental } \\
\end{array}$ & $\begin{array}{l}\text { INL } \\
\text { INL } \\
\text { INL } \\
\text { INL } \\
\text { INL } \\
\text { SRNL } \\
\text { SRNL } \\
\end{array}$ \\
\hline Glass frit & $\begin{array}{l}\begin{array}{l}\text { Powder } \\
\text { or } \\
\text { granules }\end{array} \\
\end{array}$ & $\geq 250 \mathrm{ml} \mathrm{PE}$ & 1 per batch of frit & 1 plus 1 archive & $\begin{array}{l}\text { Density } \\
\text { Elemental }\end{array}$ & $\begin{array}{l}\text { INL } \\
\text { SRNL }\end{array}$ \\
\hline $\begin{array}{l}\text { Starting } \\
\text { glass }\end{array}$ & Solid & $\geq 250 \mathrm{ml} \mathrm{PE}$ & 1 per batch of starting glass & 1 plus 1 archive & $\begin{array}{l}\text { Density } \\
\text { Elemental }\end{array}$ & $\begin{array}{l}\text { INL } \\
\text { SRNL }\end{array}$ \\
\hline $\begin{array}{l}\text { Product } \\
\text { glass }\end{array}$ & Solid & $\geq 250 \mathrm{ml} \mathrm{PE}$ & 1 per pour & $\begin{array}{l}1 \text { plus } 1 \text { archive for } \\
\text { each pour, } \sim 20 \text { total }\end{array}$ & $\begin{array}{l}\text { Density } \\
\text { Elemental } \\
\text { REDOX ratio }\end{array}$ & $\begin{array}{l}\text { INL } \\
\text { SRNL } \\
\text { SRNL }\end{array}$ \\
\hline $\begin{array}{l}\text { Melter } \\
\text { off-gas }\end{array}$ & Gas & $\begin{array}{l}\text { TO-14A } \\
\text { gas canister }\end{array}$ & $\begin{array}{l}1 \text { plus duplicate per each } \\
\text { OGSE condition }\end{array}$ & $\sim 6$ & $\begin{array}{l}\mathrm{H}_{2}, \mathrm{CH}_{4}, \mathrm{VOC} \\
\text { speciation }\end{array}$ & INL \\
\hline $\begin{array}{l}\text { Melter } \\
\text { off-gas }\end{array}$ & \multicolumn{2}{|c|}{$\begin{array}{l}\text { Gas with PM; EPA } \\
\text { Method 5/29 filters } \\
\text { absorbing solutions }\end{array}$} & $\begin{array}{l}1 \text { plus duplicate per each } \\
\text { OGSE test condition }\end{array}$ & $\sim 6$ & $\begin{array}{l}\mathrm{PM} \\
\text { Cations/metals }\end{array}$ & $\begin{array}{l}\text { INL } \\
\text { INL subcontractor } \\
\text { or SRNL }\end{array}$ \\
\hline $\begin{array}{l}\text { Scrub } \\
\text { solution }\end{array}$ & Slurry & $\geq 250 \mathrm{ml} \mathrm{PE}$ & $\begin{array}{l}1 \text { plus duplicate per each } \\
\text { OGSE test condition }\end{array}$ & $\sim 6$ & $\begin{array}{l}\text { pH } \\
\text { Density } \\
\text { TDS } \\
\text { UDS } \\
\text { TOC } \\
\text { Elemental }\end{array}$ & $\begin{array}{l}\text { INL } \\
\text { INL } \\
\text { INL } \\
\text { INL } \\
\text { SRNL } \\
\text { SRNL }\end{array}$ \\
\hline $\begin{array}{l}\text { CEMS } \\
\text { condensat } \\
\text { e }\end{array}$ & liquid & $\geq 250 \mathrm{ml} \mathrm{PE}$ & $\begin{array}{l}1 \text { per test day during OGSE } \\
\text { tests }\end{array}$ & $\sim 2$ & $\begin{array}{l}\mathrm{pH} \\
\text { TDS } \\
\text { TOC } \\
\text { Anions }\end{array}$ & $\begin{array}{l}\text { INL } \\
\text { INL } \\
\text { SRNL } \\
\text { SRNL }\end{array}$ \\
\hline \multicolumn{7}{|c|}{$\begin{array}{l}\text { 1. } \mathrm{LOI}=\text { Loss On Ignition, } \mathrm{PE}=\text { polyethylene, } \mathrm{PM}=\text { Particulate Matter, } \mathrm{TDS}=\text { total dissolved solids, } \mathrm{TOC}=\text { total organic carbon, } \mathrm{UDS}= \\
\text { undissolved solids. LOI temperature to be } 1,000^{\circ} \mathrm{C} \text { or as determined through ART CCIM project team discussion. }\end{array}$} \\
\hline \multicolumn{7}{|c|}{ 2. Only selected samples will be analyzed. } \\
\hline \multicolumn{7}{|c|}{$\begin{array}{l}\text { 3. All elemental metal cation analysis (except as noted below) and all anion analysis (except nitrate and carbonate analysis) will be done by } \\
\text { SRNL. }\end{array}$} \\
\hline \multicolumn{7}{|c|}{$\begin{array}{l}\text { 4. Elemental analysis includes any cations or metals in the feed that can be analyzed for using inductively coupled plasma atomic emission } \\
\text { spectroscopy (ICP-AES), atomic absorption spectrometry (AAS), or ICP-Mass Spectrometry (ICP-MS). The specific procedure will be } \\
\text { determined by SRNL. These cations include } \mathrm{Al}, \mathrm{B}, \mathrm{Ba}, \mathrm{Ca}, \mathrm{Ce}, \mathrm{Cr}, \mathrm{Cs}, \mathrm{Cu}, \mathrm{Fe}, \mathrm{K}, \mathrm{Li}, \mathrm{Mg}, \mathrm{Mn}, \mathrm{Na}, \mathrm{Ni}, \mathrm{P}, \mathrm{Pb}, \mathrm{S}, \mathrm{Si}, \mathrm{Zn} \text {, and } \mathrm{Zr} \text {. Alternatively, } \\
\text { those elements that are included in anion analysis ( } \mathrm{P} \text { and } \mathrm{S} \text { ) may be excluded from the cation/metals analysis, if they are included in the anion } \\
\text { analysis. }\end{array}$} \\
\hline
\end{tabular}

Table 6-4. Estimated total samples and analyses.

\begin{tabular}{|l|l|l|l|}
\hline & Estimated number of samples to be analyzed & \multicolumn{1}{|c|}{ Analyses } & Lab (b) \\
\hline 45 total samples (not & 45 samples analyzed at INL or INL & $\mathrm{pH}$ & 11 at INL \\
including archive samples) & subcontractors; & Density & 12 at INL \\
(Actual numbers may vary & 39 analyzed at SRNL & TDS & 11 at INL \\
depending on test & & UDS & 9 at INL \\
conditions, frequency of & & TOI (calcined solids) & 3 at INL \\
product collections, and & & Elemental & 11 at SRNL \\
items of interest that occur & & REDOX ratio & 31 at SRNL \\
during testing.) & & $\mathrm{H}_{2}, \mathrm{CH}_{4}$, VOC speciation & 6 at SRNL \\
& PM & 6 at INL \\
& & Cations/metals & 6 at INL subcontractor or SRNL \\
& & Anions & 2 at SRNL \\
\hline
\end{tabular}


ART CCIM Phase II-A

INL/EXT-0814449

Off-gas System Evaluation Test Plan

Table 6-5. Sample analysis procedures.

\begin{tabular}{|c|c|c|c|c|c|}
\hline $\begin{array}{l}\text { Sample } \\
\text { matrix }\end{array}$ & Analytes & Method (reference) & Analysis technique & $\begin{array}{l}\text { Typical detection } \\
\text { limits }\end{array}$ & Method summary, comments \\
\hline \multirow{8}{*}{$\begin{array}{l}\text { Liquid } \\
\text { and } \\
\text { slurry } \\
\text { samples }\end{array}$} & $\mathrm{pH}$ & $\begin{array}{l}\text { Good laboratory } \\
\text { practice }\end{array}$ & $\mathrm{pH}$ meter & 0.01 & pH meter calibrated with standards. \\
\hline & Density & $\begin{array}{l}\text { Good laboratory } \\
\text { practice }\end{array}$ & Gravimetry & $0.01 \mathrm{gm} / \mathrm{ml}$ & Measure mass of known volume in a tared container \\
\hline & TDS & $\begin{array}{l}\text { EPA Method } 5 \text { or } \\
\text { equivalent }\end{array}$ & Dry; gravimetric & $10 \mathrm{mg} / \mathrm{L}$ & Dry at $105^{\circ} \mathrm{C}$ till dry stable weight \\
\hline & UDS & $\begin{array}{l}\text { Good laboratory } \\
\text { practice }\end{array}$ & $\begin{array}{l}\text { Filter; dry and } \\
\text { weigh tared filter }\end{array}$ & $10 \mathrm{mg} / \mathrm{L}$ & Use sub-micron filter \\
\hline & LOI (calcined solids) & $\begin{array}{l}\text { ASTM D3174 or } \\
\text { equivalent }\end{array}$ & $\begin{array}{l}\text { Thermo-gravimetric } \\
\text { analysis }\end{array}$ & $10 \mathrm{mg} / \mathrm{L}$ & $\begin{array}{l}\text { Heat under oxidizing conditions to } 1,000^{\circ} \mathrm{C} \text { or as determined by the ART } \\
\text { CCIM project team; weigh residue }\end{array}$ \\
\hline & TOC & $\begin{array}{l}\text { ASTM D3176 or } \\
\text { equivalent }\end{array}$ & $\begin{array}{l}\text { Thermo-gravimetric } \\
\text { analysis }\end{array}$ & & $\begin{array}{l}\text { Heat samples at a controlled rate over a controlled time period, recording } \\
\text { differential mass losses and analyzing the gases generated over time, after } \\
\text { oxidation, using NDIR. TOC is represented by } \mathrm{CO}_{2} \text { detected at the sample is } \\
\text { heated up to about } 800^{\circ} \mathrm{C} \text {. }\end{array}$ \\
\hline & Elemental (cations/metals) & $\begin{array}{l}\text { SW-846 } 6000 \text { or } 7000 \\
\text { series or equivalent }\end{array}$ & ICP or AAS & $\begin{array}{l}1 \mathrm{mg} / \mathrm{L} ; \text { varies by } \\
\text { method and analyte }\end{array}$ & $\begin{array}{l}\text { Completely digest with appropriate acid solution, or fuse and then completely } \\
\text { digest, followed by analysis. Weigh/record any undigested mass. }\end{array}$ \\
\hline & Elemental (anions) & $\begin{array}{l}\text { SW-846 3050/9056 or } \\
\text { equivalent }\end{array}$ & $\begin{array}{l}\text { Ion chromatography } \\
\text { (IC) or equivalent }\end{array}$ & $1 \mathrm{mg} / \mathrm{L}$ & $\begin{array}{l}\text { Total digestion (of solids) per EPA } 3050 \text { or equivalent, followed by analysis } \\
\text { per } 9056 \text {. Weigh/record any undigested mass. }\end{array}$ \\
\hline \multirow[t]{4}{*}{$\begin{array}{l}\text { Solid } \\
\text { samples }\end{array}$} & Moisture & $\begin{array}{l}\text { ASTM D3273 or } \\
\text { equivalent }\end{array}$ & Gravimetry & $1 \mathrm{mg}$ & $\begin{array}{l}\text { Weigh sample, dry in oven at a temperature between } 104-110^{\circ} \mathrm{C} \text {, reweigh to } \\
\text { constant weight, calculate } \% \text { moisture. }\end{array}$ \\
\hline & Elemental (cations/metals) & $\begin{array}{l}\text { SW-846 } 6000 \text { or } 7000 \\
\text { series or equivalent }\end{array}$ & ICP or AAS & $\begin{array}{l}1 \mathrm{mg} / \mathrm{L} ; \text { varies by } \\
\text { method and analyte }\end{array}$ & $\begin{array}{l}\text { Completely digest with appropriate acid solution, or fuse and then completely } \\
\text { digest, followed by analysis. Weigh/record any undigested mass. }\end{array}$ \\
\hline & Elemental (anions) & $\begin{array}{l}\text { SW-846 3050/9056 or } \\
\text { equivalent }\end{array}$ & $\begin{array}{l}\text { Ion chromatography } \\
\text { (IC) or equivalent }\end{array}$ & $1 \mathrm{mg} / \mathrm{L}$ & $\begin{array}{l}\text { Total digestion (of solids) per EPA } 3050 \text { or equivalent, followed by analysis } \\
\text { per } 9056 \text {. Weigh/record any undigested mass. }\end{array}$ \\
\hline & $\begin{array}{l}\text { REDOX ratio }\left(\mathrm{Fe}^{+2} / \mathrm{Fe}^{\mathrm{total}} \text { ratio) }\right. \\
\text { PNNL (date unknown), SRCT } \\
\text { (date unknown) }\end{array}$ & $\begin{array}{l}\text { O. Corumluoglu } 1999 \text { or } \\
\text { equivalent }\end{array}$ & Colorimetry & $\begin{array}{l}0.05 \mathrm{wt} \% \mathrm{Fe} \text { in } \\
\text { sample before } \\
\text { dissolution }\end{array}$ & $\begin{array}{l}\text { Dissolve sample in } \mathrm{H}_{2} \mathrm{SO}_{4} / \mathrm{HF} \text { without oxidizing or reducing Fe species, } \\
\text { analyze for } \mathrm{Fe}^{+2} \text { calorimetrically, add reducing agent (Vitamin } \mathrm{C} \text { ) to reduce } \\
\mathrm{Fe}^{+3} \text { to } \mathrm{Fe}^{+2} \text { and re-analyze for } \mathrm{Fe}^{+2}\end{array}$ \\
\hline \multirow[t]{3}{*}{$\begin{array}{l}\text { Off-gas } \\
\text { grab } \\
\text { samples }\end{array}$} & PM and metals & EPA Method 5/29 & $\begin{array}{l}\text { Gravimetry (PM) } \\
\text { ICP or AAS } \\
\text { (metals) }\end{array}$ & $\begin{array}{l}0.9 \mathrm{mg} / \mathrm{dscm}(\mathrm{PM}) \\
0.5 \mathrm{ug} / \mathrm{dscm} \\
\text { (metals) }\end{array}$ & $\begin{array}{l}\text { Modify EPA Method } 5 / 29 \text { for small-pipe, single-point sampling. Dry PM } \\
\text { samples at } 105^{\circ} \mathrm{C} \text { till dry stable weight. Digest metals samples per SW- } 846 \\
\text { methods } 3050 / 3051 \text { and analyze per Method } 6020 \text {, or equivalent methods. }\end{array}$ \\
\hline & Metals & EPA Method 29 & ICP or AAS & $\begin{array}{l}1 \mathrm{mg} / \mathrm{L} \text {; varies by } \\
\text { method and analyte }\end{array}$ & $\begin{array}{l}\text { Document visible particle properties - shape, appearance, etc. Count numbers } \\
\text { of particles within selected size ranges in the field of view or in grids in the } \\
\text { field of view }\end{array}$ \\
\hline & $\mathrm{H}_{2}, \mathrm{CH}_{4}, \mathrm{VOC}$ speciation & $\begin{array}{l}\mathrm{H}_{2}, \mathrm{CH}_{4}: \text { ACMM- } 9925 \\
\text { VOCs: ACMM-9930 }\end{array}$ & $\begin{array}{l}\mathrm{H}_{2}, \mathrm{CH}_{4}: \mathrm{GC} \\
\text { VOCs: GC/MS }\end{array}$ & & $\begin{array}{l}\text { Field sample collection in evacuated stainless steel sample canisters. The } \mathrm{H}_{2} \\
\text { and } \mathrm{CH}_{4} \text { analysis is similar to EPA Method } 18 \text {. The VOC analysis procedure } \\
\text { is similar to the EPA TO-14A. }\end{array}$ \\
\hline
\end{tabular}




\section{QUALITY ASSURANCE}

A Quality Level Determination (QLD), compliant with INL quality level requirements, has been performed for this test program. Quality Level 3 (Low) was determined for all aspects of the test program (Calculations, Configuration Management, etc.) except for Design Control, which was assigned Quality Level 2, because of its medium risk to the test program.

Key process monitoring, safety-related, and off-gas characterization instruments and the data collection loops are calibrated for safety and accuracy. Key process instrumentation including flowmeters, pressure sensors, and temperature sensors have been calibrated. Calibration records are retained by the project team.

Quantitative and qualitative measurements that estimate the true value or actual concentration of a physical or chemical property always involve some level of uncertainty. If the level of uncertainty in the data can be quantified in terms of standard parameters, these can be compared to project-specific data quality objectives (DQOs), designed to quantify and qualify the level of uncertainty for the test results to meet the test objectives. The quantitative metrics for the quality of environmental data are precision $(\mathrm{P})$, accuracy (A), and completeness $(\mathrm{C})$. The qualitative metrics for data quality are representativeness (R) and comparability $(\mathrm{C})$. These parameters are referred to as "PARCC" parameters.

Precision is a measure of the agreement among individual measurements of the same parameter under similar conditions.

Accuracy is the degree of agreement of a measurement with a true or known value.

Representativeness is a measure to which sample data accurately and precisely represent the average properties being measured.

Comparability is the determination that one data set can be compared to another. This qualitative characteristic involves all aspects of the work, including preparation for sampling, sampling, sample handling, analytical method performance, data validation, and reporting of results.

Completeness is a measure of the amount of valid data compared to the amount expected under normal conditions.

\subsection{Data Quality Objectives}

The DQOs establish the degree of quality assurance/quality control (QA/QC) required to meet the data quality needs of the test objectives. Table 7-1 summarizes the DQOs for each test objective of this test plan. This table also shows whether each objective is critical (C) or non-critical (NC). Finally, the type of data for each objective is identified as either quantitative (Quant) or qualitative (Qual).

Qualitative QA parameters are comparability and representativeness. Comparability and representativeness in this project are achieved by the following:

- Collecting samples and making measurements from specific approved locations in the test system

- Using standard procedures for calibrations

- Using approved sampling and analytical procedures based on standard methods

- Documenting and technically defending all necessary deviations from standard procedures, sample preparation methods, or analytical methods

- Complying with defined requirements for review of analytical results

- Using standard approved procedures for all data reductions and emissions calculations. 


\subsection{Quantitative Measurements}

Quantitative DQOs are summarized in Table 7-2 for individual analyses and measurements. These DQOs are not intended to include all QA/QC activities performed in the field or laboratory. Many sampling and analytical methods specify more QA/QC activities than are included here. Those listed here are those that are identified for this project to be practical to perform, track, and report, are readily quantifiable, and provide the best indicators of precision and accuracy.

A completeness goal of $80 \%$ to $100 \%$ for different measurements, rather than $100 \%$ for all measurements, was determined to be appropriate for this project. This allows for some limited loss of valid data, whether in the field or in the laboratory, regardless of the reason, without necessitating retests or other costly and impractical measures to provide additional data. A completeness goal of $80 \%$ for most of the measurements is adequate for the intended test data uses.

\subsection{Detection Limits}

Detection limits are defined and determined different ways for different methods. In general, the lowest possible detection limit is defined as a method detection limit (MDL) or an instrument detection limit (IDL). Target or typical detection limits for the various laboratory measurements are listed along with laboratory analyte lists in Section 6. If these detection limits are achieved, then the resultant data can be used to meet the test objectives. Actual detection limits may vary from these targets due to matrix interferences, sample splits, dilutions, or concentrations.

Table 7-1. Data Quality Objectives.

\begin{tabular}{|l|c|c|c|l|}
\hline \multicolumn{1}{|c|}{ Test Objective } & C/NC & Quant & Qual & \multicolumn{1}{|c|}{ DQOs } \\
\hline $\begin{array}{l}\text { Operate the melter system over a range of operating } \\
\text { conditions while feeding a feed composition } \\
\text { representing the SRS sludge simulant }\end{array}$ & $\mathrm{C}$ & & $\mathrm{X}$ & $\begin{array}{l}\text { Obtain data that shows the range of } \\
\text { melter system operating conditions while } \\
\text { feeding SRS sludge simulant }\end{array}$ \\
\hline $\begin{array}{l}\text { Determine the melter off-gas source term to the off- } \\
\text { gas system. }\end{array}$ & $\mathrm{C}$ & $\mathrm{X}$ & $\mathrm{X}$ & $\begin{array}{l}\text { The melter outlet off-gas measurements } \\
\text { must provide the off-gas composition, } \\
\text { and flowrates of gaseous and aerosol } \\
\text { species. }\end{array}$ \\
\hline $\begin{array}{l}\text { Determine compositions and masses of the product } \\
\text { glass and scrub solution, and the glass REDOX } \\
\text { levels as indicated by the REDOX ratio } \\
\text { (Fe+2/Fetotal). }\end{array}$ & $\mathrm{NC}$ & $\begin{array}{l}\text { Melter feed and off-gas measurements } \\
\text { must provide data for determining the } \\
\text { destruction efficiency of total organics in } \\
\text { the feed. }\end{array}$ \\
\hline $\begin{array}{l}\text { Determine the fate of key feed constituents (glass } \\
\text { formers, radionuclide surrogates, heavy metal } \\
\text { surrogates, nitrates/nitrites, and acid gases), for } \\
\text { selected melter operating conditions. }\end{array}$ & $\mathrm{C}$ & $\mathrm{X}$ & $\mathrm{X}$ & $\begin{array}{l}\text { Melter feed, melter off-gas, and glass } \\
\text { product measurements must provide data } \\
\text { to determine partitioning of feed } \\
\text { constituents to the off-gas, aerosols in the } \\
\text { off-gas, or glass product. }\end{array}$ \\
\hline $\begin{array}{l}\text { Notes: } \\
1 . \text { C = critical, NC = noncritical; Quant - quantitative, Qual = qualitative }\end{array}$ & & \\
\hline
\end{tabular}


ART CCIM Phase II-A

INL/EXT-0814449

Off-gas System Evaluation Test Plan

Table 7-2. Precision, accuracy, and completeness objectives for critical measurements.

\begin{tabular}{|c|c|c|c|c|c|c|}
\hline Measurement & Method & Method of determining precision & Method of determining accuracy & Precision & Accuracy & $\begin{array}{c}\text { Completeness, } \\
\%\end{array}$ \\
\hline \multicolumn{7}{|l|}{ Process measurements } \\
\hline Simulant feedrate & $\begin{array}{l}\text { Volumetric } \\
\text { or mass } \\
\text { flowmeter }\end{array}$ & --- & $\begin{array}{l}\text { Calibrations using timed trials and } \\
\text { gravimetry }\end{array}$ & --- & $\pm 3 \%$ of full scale & 100 \\
\hline Bubbler air flowrate & Rotameter & --- & Bubble flowmeter & --- & $\pm 5 \%$ of full scale & 80 \\
\hline Bubbler dP & manometer & --- & $\begin{array}{l}\text {--- (liquid manometer is reference } \\
\text { method) }\end{array}$ & $\begin{array}{ll}-- \\
\end{array}$ & --- & 80 \\
\hline $\begin{array}{l}\text { All logged } \\
\text { temperatures }\end{array}$ & TCs & $\begin{array}{c}-- \\
-1\end{array}$ & $\begin{array}{l}\text { 2-point calibration using reference } \\
\text { thermometers or reference TCs }\end{array}$ & $\begin{array}{ll}-- \\
-1\end{array}$ & $\begin{array}{c} \pm 2 \% \text { of the } \\
\text { measured value } \\
\text { (absolute) }\end{array}$ & 80 \\
\hline $\begin{array}{l}\text { All gravimetric } \\
\text { measurements (product } \\
\text { weights, density, TDS, } \\
\text { UDS, PM, LOI, etc.) }\end{array}$ & Gravimetry & $\begin{array}{l}\text { RPD of analysis for at least one } \\
\text { set of identified duplicate samples }\end{array}$ & $\begin{array}{l}\text { 2-point calibration of weigh scales } \\
\text { using traceable weights }\end{array}$ & $\begin{array}{l}-- \\
-1\end{array}$ & $\pm 1 \%$ of full scale & 80 \\
\hline $\begin{array}{l}\text { All logged pressures, } \\
\text { differential pressures }\end{array}$ & $\begin{array}{l}\text { Pressure } \\
\text { transducers }\end{array}$ & --- & $\begin{array}{l}\text { Calibration using manometer or } \\
\text { traceable pressure gauge }\end{array}$ & $\begin{array}{ll}-- \\
-1\end{array}$ & $\pm 2 \%$ of full scale & 80 \\
\hline $\begin{array}{l}\text { All logged mass } \\
\text { flowmeters }\end{array}$ & $\begin{array}{l}\text { Thermal } \\
\text { conductivit } \\
\text { y or } \\
\text { coriolis }\end{array}$ & $\begin{array}{ll}-- \\
-1\end{array}$ & $\begin{array}{l}\text { 2-point calibration using bubble } \\
\text { flowmeter or reference flowmeter }\end{array}$ & $\begin{array}{ll}-- \\
-1\end{array}$ & $\pm 2 \%$ of full scale & 80 \\
\hline \multicolumn{7}{|l|}{ Sample Analysis } \\
\hline $\mathrm{H}_{2}, \mathrm{CH}_{4}$ & GC & $\begin{array}{l}\text { RPD of analysis for at least one } \\
\text { set of identified duplicate samples }\end{array}$ & $\begin{array}{l}\text { multi-point point calibration using } \\
\text { calibration }\end{array}$ & $\begin{array}{l}+10 \% \\
\text { RPD }\end{array}$ & $\begin{array}{l} \pm 10 \% \text { of full } \\
\text { scale }\end{array}$ & 80 \\
\hline VOCs & GC/MS & $\begin{array}{l}\text { RPD of analysis for at least one } \\
\text { set of identified duplicate samples }\end{array}$ & $\begin{array}{l}\text { multi-point point calibration using } \\
\text { standard solutions }\end{array}$ & $\begin{array}{l}+10 \% \\
\text { RPD }\end{array}$ & $\begin{array}{l} \pm 10 \% \text { of full } \\
\text { scale }\end{array}$ & 80 \\
\hline
\end{tabular}

$\mathrm{RPD}=$ Relative percent difference $=2 \times($ Measurement $2-$ Measurement 1$) /($ Measurement $1+$ Measurement 2$) \times 100$ 


\subsection{Sample Handling and Custody}

Gaseous, liquid, and solid samples will be collected for analysis in this test program. Sample containers will be appropriate to the sample matrix, summarized in Section 6. All containers are to be kept in a clean environment until needed, preferably in original shipping boxes, and covered, if necessary, to minimize accumulation of dusts. New or used containers without cleanliness certification may be used as long as they are washed and prepared for the specific use.

All samples shall be labeled with a unique identifying number and with other information that describes the sample to field, shipping, and laboratory personnel. The label must identify the unique sample number, project name, sample description, sample date and time, and sampler name or initials. The sample description will include the location of sample collection and the sample matrix. This same information along with any additional detail information including sample volume or weight, requests for analysis, and chain of custody information shall recorded in a sample log and on request for analysis/chain of custody (RFA/COC) forms.

Hazardous samples such as the gas samples that are transported to INL laboratories for analysis are regulated by DOT. DOT provides a "Materials of Trade Exception" (49 CFR 173.6), that can allow the stainless steel gas canisters to be transported using the following procedures (Rowley 2003):

- The samples should be secured in an outer container so that there would not be breakage, leakage, or spillage during transportation (the stainless steel canisters meet this requirement).

- Package the canisters into an outer container like an open head drum, cooler, or fiberboard box and secure the canisters inside with enough packing material to prevent movement in the outer container during transport.

- Secure the container of canisters in a government vehicle so that there will not be movement or spillage and be protected against damage.

- The driver needs to have on him/her their driver's license and be aware of the hazards he or she is carrying.

Samples prepared for commercial shipment to SRNL should be prepared as follows:

- Label samples (this should be done at the time of sample collection/recovery).

- Verify that the labeling is correct, there is sufficient sample volume, and that the lid seal is tight.

- Mark liquid levels on the container outer surface with a marker or tape that will not wash or wipe off during handling or shipment.

- If the containers may become wetted (from wet ice packaging, for example), cover sample labels with transparent packing tape so it cannot peel off if wetted.

- Seal the sample containers that contain liquids inside a zip-lock bag which is evacuated to prevent bursting when packed.

- Prevent breakage of any glass sample containers by wrapping and taping the bagged container inside plastic bubble wrap. The tape used should be impervious to moisture and cold. Acceptable tapes include transparent packing tape or duct tape.

- Label wrapped, bagged samples with the sample label information (at least the unique sample number) so the wrapping does not need to be removed to identify the sample.

- Place the samples in the appropriate transfer or shipping container, with specified preservation, and added packing materials so that the samples are held in place.

- No sample shipments should be made on Fridays or Saturdays, without ascertaining that any unplanned holdups in shipment or receipt due to weekends or holidays will be avoided, or will 
not result in sample deterioration due to transport times or temperature exposures outside of their allowable ranges.

- Chain-of-custody and request for analysis forms must accompany the samples within the shipping/transport containers. If wet ice is used for container cooling, COC and RFA forms will be sealed into plastic zipper bags that are taped to the inner lid of the shipping container. Each shipped container will have its own airbill number. Multiple shipping containers will not be combined on a single airbill.

The analytical laboratory assumes custody of samples upon receipt of sample shipments by signature on the RFA/COC forms that accompany the samples. The laboratory is also responsible for maintaining the necessary sample preservations and hold times.

The laboratory must track and document location of project samples at all times from receipt until final report release or release to disposition archived and sample residues. The tracking system must readily identify individual samples, sample extracts, and sample aliquots via a documented crossreferencing system that relates sample field identifiers to identifiers assigned by laboratory during sample receipt, sample aliquot preparations, and sample extracts.

\subsection{Data Reduction, Review, Validation And Reporting}

\subsubsection{Data Reduction and Presentation}

All process data and CEMS data will be recorded manually on data sheets and recorded automatically in electronic data files. The electronic data files will be imported into spreadsheet formats for use in data reduction and presentation. Spreadsheets and other calculation software shall have documentation of verification and validation of the software unless it is embedded into dedicated equipment or is commercially available for this particular application.

Onsite data reduction will be performed to the extent possible. Process data from the DACS will be incorporated with CEMS data and available sample analysis data to characterize the process inputs, outputs, operating conditions. The data will be used to determine mass balance closure and fate of key feed constituents.

The CEMS data reductions will include:

- Calculate instantaneous and average off-gas composition for selected time periods

- Calculate CEMS zero and span drifts

- Correct CEMS data for calculated drift if zero or span drift exceeds acceptance limits

- Correct CEMS data for any dilutions

- Normalize concentrations to representative bases were applicable (such as dry, $7 \%$ excess $\mathrm{O}_{2}$ basis, or wet basis)

\subsubsection{Data Validation}

All calculations in the DACS and in data reduction spreadsheets will be validated by hand calculations at the time the calculations are entered into the software. Calculations will also be validated by checking a limited sampling of hand calculations or by limited comparisons to other validated test results from prior tests.

Laboratory data will be flagged if conditions during analysis such as proximity to detection limits or full-scale values, interferences, or blank values cause the data to be suspect. 


\subsection{Internal Quality Control Checks and Specific Routine Procedures for Quality Assurance}

Internal quality control checks for this project shall include quality assurance/quality control (QA/QC) samples, calibration checks, lot controls, equipment maintenance and handling, and protocols or procedures specified in each of the sampling and analysis methods.

QA/QC samples include blank and duplicate samples. Duplicate samples will be used to indicate analytical precision. Container and lot documentation will be retained for reagents and chemicals used in the test program. Should blank or sample analyses indicate quality issues for these materials the container and lot information will be used to determine if more analyses are needed or if test results can be adjusted to improve accuracy and validity.

Test system and sampling equipment will be inspected when it is used for functionality, cleanliness, wear, corrosion, or other issues that could affect its performance for this test program. The CEMS operations will include routine inspections and maintenance of all components, leak checks, zero and span calibrations, linearity checks, bias checks, interference checks, drift checks, sample gas flowrate and pressure monitoring and control, dilution checks, and temperature monitoring and control.

Test personnel will use laboratory notebooks, checklists, operator aids, data sheets, and log books to maintain orderly and well documented records of the test program.

\subsection{Corrective Actions}

Changes to this test plan will be documented in subsequent test plan versions or in other written documentation approved by the test leader and disseminated to the test team. Changes that may affect successfully achieving the primary test objectives will be made only upon concurrence by the ART CCIM project management.

\section{ENVIRONMENTAL, HEALTH, AND SAFETY}

Safety of personnel during operations is the overriding priority of all testing. INL shall ensure that employees and observers are aware of potential hazards and mitigations that could be encountered during the test. INL will provide the necessary personal protective equipment, monitoring equipment and postings. All personnel shall have the option to initiate a stop work order if an unsafe condition is observed.

This test program is determined to be within the scope of the current version of the INL Laboratory Instruction (LI) "Cold Crucible Induction Melter (CCIM)" Project (13666-089-IEDF). This document was prepared by the test project team and reviewed and approved by a team of subject matter experts outside of the project team. This document is the document that provides authorization by INL management, Laboratory Manager, and Laboratory Space Coordinator to perform the work covered in this test plan. This document identifies hazards and mitigation of those hazards, consistent with the Integrated Safety Management System (ISMS), which incorporates the following phases:

- Define the scope of work

- Analyze the hazards

- Develop and implement hazard controls

- Perform the work within controls

- Provide feedback and continuous improvement 
Safety during testing under this LI is provided through engineering controls where possible, with additional administrative controls. Engineering controls include the use of barriers that prevent potential equipment damage or exposure of personal to physical hazards, pressure relief valves where necessary, equipment interlocks that prevent access to or use of equipment without ensuring safe conditions, and secondary containment of potential spills. Administrative controls include training of operating personnel and observers, work in compliance with that training, compliance with applicable operating procedures, operation within acceptable limits for equipment, and implementation of specified corrective actions in the event that operating conditions exceed acceptable limits.

Environmental protection for this project is provided by compliance to the chemical inventory and waste handing sections of the LI, Environmental Checklist, and the Air Permit Applicability Determination (APAD) for this project.

\section{REFERENCES}

Corumluoglu, O. and E. Guadagnino (compilers) 1999, "Determination of Ferrous Iron and Total Iron in Glass by a Colorimetric Method - Report of ICG/TC," Glass Technology, 40[1], pages 24-28.

EPA 1999, Compendium Method TO14A, "Determination of Volatile Organic Compounds (VOCs) in Ambient Air Using Specially-Prepared Canisters with Subsequent Analyzed by Gas Chromatography," EPA/625-R-96/010b, January.

Girold, C. et al, 2008, CEA memo to the ART CCIM Phase II-A team, "Proposed Configuration and Operating Conditions for the INL Test," 10 September.

Marra, Jim, et al, "Glass Formulation Development and Testing for Cold Crucible Induction Melter Technology Retrofit and Deployment Project, Phase II-A - Demonstrations, Lab-Scale Evaluation and Assessment Final Report," Draft, SRNS-STI-2008-00036, August xx, 2008.

PNNL (date unknown), "Iron Two/Total Iron Ratio," PNNL Procedure APSLO-2, 15 pages.

Rowley, Debbie, 2003, personal communication to Nick Soelberg, 16 July.

SRTC (date unknown), "Determining $\mathrm{Fe}^{2} / \mathrm{Fe}^{3}$ and $\mathrm{Fe}^{2} / \mathrm{Fe}^{\text {total }}$ Using the HP8452A Diode Array Spectrometer," procedure 1.8 Rev. 1, SRTC Mobile Laboratory Procedure.

Stone, Mike, 2008, Savannah River National Laboratory, "SB4 Melter Feed Compositions Mar 26 08.xls," March 26, 2008. 